(2) norden 



\section{Det nordiske arbeidsmarked to år etter EU-utvidelsen}

Mobilitet, virkninger og utfordringer

Jon Erik Dølvik og Line Eldring, Fafo 
Det nordiske arbeidsmarked to år etter EU-utvidelsen

- Mobilitet, virkninger og utfordringer

TemaNord 2006:557

(C) Nordisk Ministerråd, København 2006

ISBN 92-893-1369-2

Trykk: Ekspressen Tryk \& Kopicenter

Opplag: 350

Trykt på miljøvennlig papir som oppfyller kravene i den nordiske miljøsvanemerkeordning.

Publikasjonen kan bestilles på www.norden.org/order. Flere publikasjoner på

www.norden.org/publikationer

Printed in Denmark

Nordisk Ministerråd

Store Strandstræde 18

1255 Copenhagen $\mathrm{K}$

Telefon (+45) 33960200

Fax (+45) 33960202

www.norden.org

\section{Nordisk Råd}

Store Strandstræde 18

1255 Copenhagen $\mathrm{K}$

Telefon (+45) 33960400

Fax (+45) 33111870

\section{Det nordiske samarbeidet}

Det nordiske samarbeidet er et av de eldste og mest omfattende regionale samarbeider i verden. Det omfatter Danmark, Finland, Island, Norge og Sverige samt Færøyene, Grønland og Åland. Samarbeidet styrker samhørigheten mellom de nordiske land med respekt for de nasjonale forskjeller og likheter. Det øker mulighetene for å hevde Nordens interesser i omverdenen og fremme det gode naboskap.

Samarbeidet ble formalisert i 1952 med Nordisk Råds opprettelse som forum for parlamentarikerne og regjeringene i de nordiske land. I 1962 underskrev de nordiske land Helsingforsavtalen, som siden har vært den grunnleggende rammen for det nordiske samarbeidet. I 1971 ble Nordisk Ministerråd opprettet som det formelle forum til å ivareta samarbeidet mellom de nordiske regjeringer og den politiske ledelsen i de selvstyrende områder, Færøyene, Grønland og Åland. 


\section{Forord}

Utvidelsen av EU i 2004, og dermed også EØS-området, har hatt stor betydning for de nordiske landene. Det var frykt for at utvidelsen skulle skape alvorlige problemer for arbeidsmarkedene som førte til at alle de nordiske landene, med unntak av Sverige, innførte overgangsregler for arbeidsinnvandrerne fra de nye EØS-landene. Landenes forskjellige valg av løsninger og overgangsregler gjorde det naturlig og viktig å starte opp et nordisk samarbeidsprosjekt for å følge med på hva som skjedde. Etableringen av en nordisk arbeidsgruppe, med deltakere fra de ulike ansvarlige myndigheter, og med forskningsstiftelsen Fafo som sekretariat, har bidratt til gjensidig informasjonsutveksling og systematisering av kunnskaper på tvers av landegrensene. Dette har vært til stor nytte for myndighetene i alle landene. Samtidig har rapportene fra arbeidsgruppen bidratt til den nordiske debatten om den nye arbeidsinnvandringens effekter på arbeidsmarkedet og virkninger av de ulike typene overgangsordninger som ble valgt.

Samarbeidsprosjektet har dokumentert at det utvidede, åpne europeiske arbeidsmarkedet har hatt positive effekter. Norden har som følge av en positiv konjunkturutvikling, mangel på arbeidskraft i flere sektorer. Polakkene, estlenderne, latvierne, litauerne og de andre som reiser nordover for å arbeide dekker derfor et behov i de nordiske landene. Samtidig vil det å kunne komme til Norden for å jobbe være en god mulighet for mange arbeidstakerne fra de nye medlemslandene til å bedre sin livssituasjon.

Arbeidsinnvandring er altså positivt for alle parter! Men vi må sørge for at den foregår i ordentlige former, slik at arbeidstakerne ikke utnyttes, lures eller utsettes for uverdige lønns- og arbeidsforhold. Og slik at alle de virksomhetene som driver seriøst ikke utsettes for urimelige konkurransevilkår, basert på ulovligheter. Det er også av sentral betydning for våre nordiske velferdssamfunn at ikke deler av arbeidslivet blir preget av svart arbeid, skatteunndragelser og økonomisk kriminalitet. Samarbeidsprosjektet har kunnet dokumenterte problemer knyttet til såkalt sosial dumping, dvs. at arbeidstakerne fra de nye EØS-landene jobber på vesentlig dårligere vilkår enn nasjonale, nordiske arbeidstakere. Også omgåelser av gjeldende regelverk og overgangsordninger er blitt dokumentert. Prosjektet har dermed gitt oss kunnskap og bakgrunn for å kunne iverksette nødvendige tiltak for å hindre uønskede effekter.

Nettopp kunnskap om hva som skjer, hvem som kommer og hvordan de behandles, gjør dette nordiske prosjektet så viktig. Det å få bedre kunnskap om arbeidsinnvandringen fra de nye EØS-landene etter 2004 er sentralt for å kunne iverksette tiltak som kan forhindre sosial dumping og 
ulovlige forhold, og sikre at arbeidsinnvandringen blir positiv for alle parter. Samtidig er det også svært nyttig å få kartlagt likheter og ulikheter mellom de nordiske landene, både for bedre å kunne forstå hvilke mekanismer som gjør seg gjeldende og for å kunne lære av hverandres utfordringer og problemløsning. Rapportene som kommer fra samarbeidsprosjektet peker på flere sentrale problemstillinger knyttet til reguleringene av de nordiske arbeidsmarkedene nå og i fremtiden, problemstillinger som er viktige og nødvendige å forholde seg til, for myndighetene, for partene i arbeidslivet og alle andre aktører på arbeidsmarkedet.

Jeg vil takke arbeidsgruppen og Fafo som har bidratt til rapportene og det kunnskapsgrunnlaget vi nå har fått.

Bjarne Håkon Hanssen

Arbeids- og inkluderingsminister

Oslo 18. august 2006 


\section{Innhold}

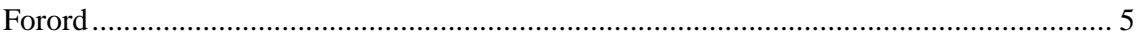

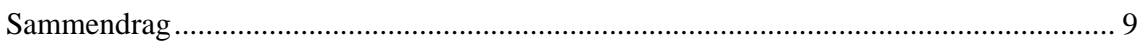

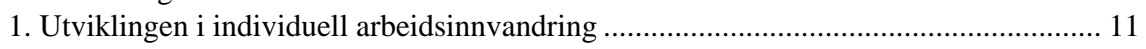

2. Økende tjenestemobilitet og utstasjonering av arbeidstakere ....................................... 21

2.1 Regulering av lønns- og arbeidsvilkår for utstasjonerte arbeidstakere ................. 23

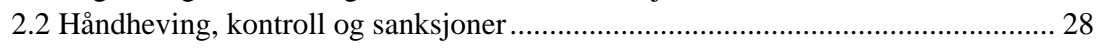

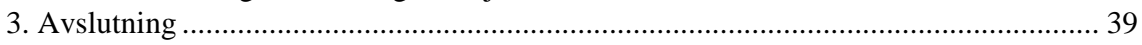

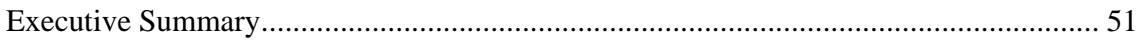

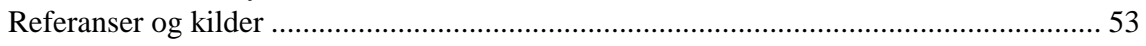

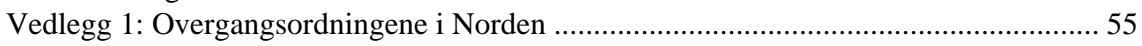

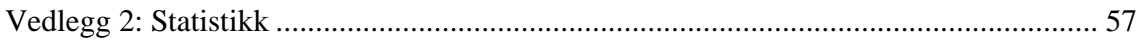

Vedlegg 3: Liste over kontaktgruppens medlemmer .......................................................... 59 



\section{Sammendrag}

(1) To år etter EU-utvidelsen har det tegnet seg et visst mønster i arbeidsvandringene fra de nye EU-landene til Norden. Den individuelle arbeidsmigrasjonen har variert sterkt mellom de nordiske landene, men fortsetter å øke. Ved å dekke økende behov for arbeidskraft, har arbeidsinnvandringen bidratt til økt vekst i produksjon og sysselsetting, dempet pris- og renteutvikling, og utvidet handlefriheten i den økonomiske politikken. Veksten i arbeidsinnvandring har vært sterkest i Norge og på Island, mens Sverige og Finland har sett en viss nedgang i den registrerte migrasjonen. Det er ikke registrert tegn til sosial turisme. Arbeidsmobiliteten knyttet til tjenesteyting har økt kraftig og synes i viktige sektorer klart større enn den ordinære arbeidsmigrasjonen. Dette har reist nye utfordringer når det gjelder regulering, håndheving og kontroll.

(2) I likhet med de fleste 'gamle EU-land, valgte Danmark, Finland, Island og Norge i 2004 å innføre overgangsordninger for bevegelse av arbeidstakere fra EU-8. Sverige og i praksis Storbritannia og Irland åpnet sitt arbeidsmarked fra første dag. Fra 1.mai 2006 opphevet Finland, Island, Hellas, Portugal og Spania sine overgangsordninger, nylig etterfulgt av Italia. Danmark foretok en oppmykning og gjorde det mulig å forhåndsgodkjenne bedrifter med tariffavtale og vil i likhet med Norge seinest oppheve sin ordning 1.mai 2009. Dessuten har andre EU-land varslet en gradvis åpning av arbeidsmarkedet i tiden framover, slik at det med unntak for Østerrike og Tyskland dermed trolig vil være et åpent arbeidsmarked i det nåværende EU/EØS fra 1.mai 2009. Mye tyder imidlertid på at flere land vil benytte retten til overgangsordning hvis/når Bulgaria og Romania blir medlem.

(3) De nordiske erfaringene har understreket vanskene med å ha ulike regimer for individuell arbeidsmigrasjon og arbeidsmobilitet via tjenesteyting. Forskjeller i vilkårene for lønnsdannelse, arbeidsforhold, skatt/avgifter, kontroll og håndheving, har gitt opphav til strategiske omgåelser og vridningseffekter. Dette har bidratt til redusert regulær arbeidsinnvandring og konkurransevridning, lønnsdumping og uryddige forhold i deler av arbeids- og tjenestemarkedene. Man har også sett økende tegn til illegal sysselsetting av migranter, blant annet i husholdssektoren.

(4) Ved utfasingen av overgangsordningene utvides de legale mulighetene for sysselsetting av arbeidstakere fra EU-8 i bedrifter med lavere lønn enn det som er gjengs i det nasjonale arbeidsmarkedet. Spesielt i land/sektorer med begrenset avtaledekning og/eller uten ordninger for allmenngjøring av tariffavtaler/minstelønn, kan dette åpne for forskjellsbehandling, økt lavlønnskonkurranse og press på avtalesystemet og lønns- og arbeidsvilkår. Når grensekontrollen opphører, skjerpes kravene 
til det interne regulerings- og kontrollregimet i arbeidsmarkedet. Utfordringen er å utvikle en politikk for arbeidsmigrasjon som sikrer likeverdig samspill mellom tjeneste- og arbeidsmigrasjon, likebehandling av utenlandske arbeidstakere, og tar høyde for - og kan påvirke - vilkårene for fri bevegelse i det åpne europeiske markedet.

(5) Med et høyt velferdsnivå og aldrende befolkning, reiser det åpne europeiske arbeids-og tjenestemarkedet krevende dilemmaer for de nordiske land. Behovet for arbeidskraft øker og vil på sikt neppe kunne dekkes innen Norden. I de nye EU-landene vil aldersbølgen bli sterkere og lønns- og velstandsveksten øker. I årene framover vil man trolig se tiltakende kamp om arbeidskraft i Europa og (selgers marked) for tjenesteoppdrag. Etterspørselen etter arbeidskraft fra 3.land og presset langs EU/EØSs yttergrense vil antakelig øke. Dette vil stille krav til utforming av en mer helhetlig og langsiktig politikk for arbeids- og tjenestemobilitet både nasjonalt, i Norden og på europeisk plan. 


\section{Utviklingen i individuell arbeidsinnvandring ${ }^{1}$}

(6) Danmark, Finland, Island og Norge benyttet i 2004 muligheten til å innføre en to-årig overgangsordning som la visse begrensninger i adgangen for personer fra de nye medlemslandene, mens Sverige åpnet arbeidsmarkedet fra første dag. I løpet av de første to årene rapporterte ingen av landene om vesentlige forstyrrelser eller ubalanser i arbeidsmarkedet. Ordningene har bidratt til en viss oversikt og kontroll med tilgangen på arbeidskraft, men den lave registrerte individuelle innvandringen i flere av landene førte til diskusjon om ordningene virker uhensiktsmessig begrensende på rekrutteringen av ønsket arbeidskraft. Overgangsordningene kan forlenges fram til 1 . mai 2009, med mulighet til ytterligere forlengning fram til 2011 dersom det er risiko for alvorlige forstyrrelser i arbeidsmarkedet. Landene med overgangsordninger måtte dermed våren 2006 beslutte hvorvidt overgangsordningene skulle oppheves, forlenges eller revideres. Igjen valgte de nordiske landene ulike løsninger, og ulik takt i utfasingen av overgangsordningene. Finland og Island har opphevet sine ordninger, mens Danmark og Norge foreløpig opprettholder overgangsregimene, med en viss oppmyking i Danmark.

(7) Ett år etter utvidelsen var det ikke kommet noen stor strøm av arbeidssøkere til Norden, men det var betydelige forskjeller mellom landene. Ved utgangen av 2005 kunne en konstatere at variasjonene i omfanget av registrert individuell arbeidsinnvandring til de nordiske landene fortsatte og delvis ble forsterket, samtidig som tilflyten var voksende, med unntak for Sverige (hvor kun arbeidsopphold over 3 måneder registreres). ${ }^{2}$ I 2005 ble det i Norden samlet utstedt nesten 34000 førstegangstillatelser til nye EU-borgere, samt 19000 fornyelser, hvorav Norge stod for de fleste (se vedlegg 2, tabell 1). Sammenliknet med 2004, opplevde Island sterk vekst i 2005 (mer enn tredobling til 3 608, inklusive fornyelser), Danmark en fordobling (til 4 594), mens økningen i Finland var beskjeden, og Sverige registrerte en viss nedgang. I Norge var det over 40 prosent vekst, til 37203 innvilgete tillatelser (inklusive fornyelser). Totalt

\footnotetext{
${ }^{1}$ Tusen takk til deltakerne i prosjektets kontaktgruppe for et svært godt samarbeid gjennom året, og for nyttige kommentarer til rapportutkastet (se vedlegg 3 for liste over deltakerne i kontaktgruppen). Takk også til Norges Forskningsråd for støtten til Fafos arbeid på feltet, som vi har trukket betydelige veksler på i arbeidet med rapporten.

${ }^{2}$ Se også Dølvik, Jon Erik og Line Eldring (2005), Arbeids- og tjenestemobilitet etter EUutvidelsen. Nordiske forskjeller og fellestrekk. Sluttrapport for en arbeidsgruppe under Nordisk Ministerråd. TemaNord 2005:566, og Dølvik, Jon Erik og Line Eldring (2006), Statusrapport Januar 2006: EU-utvidelsen og konsekvensene for arbeidsmobiliteten til Norden. Halvårsnotat fra Arbeidsgruppe under Nordisk Ministerråds Arbeidsmarkedsutskott og Friberg, J.H. (2006), Individuell arbeidsinnvandring. Utfordringer to år etter EU-utvidelsen. Fafo Østforum/Fafo-notat 2006:07
} 
sett var det ved inngangen til 2006 i Norden innvilget minst 59499 førstegangstillatelser/søknader om EØS-tillatelser fra EU-8-borgere siden 1.mai 2004, samt 22970 fornyelser. Norge hadde utstedt mer enn 2/3 av tillatelsene i Norden siden 1.mai 2004 - 36276 førstegangstillatelser og 21460 fornyelser - til sammen 57 736, hvorav en vesentlig del var korttidsarbeid. I Vest-Europa for øvrig ble det i 2004-5 registrert størst tilstrømming til Tyskland (500 000 tillatelser), Storbritannia (160 000) og Irland $(110000)^{3}$. I juni 2006 rapporteres det fra Irland om unikt stor innvandring, og at hele 200000 personer har innvandret fra de nye medlemslandene i løpet av den første toårsperioden, ${ }^{4}$ mens England ved utgangen av mars hadde registrert 391000 arbeidsinnvandrere fra EU-8.

(8) Med utgangspunkt i tall for første halvår 2006, kan vi nå gjøre opp status for de første to årene etter EU-utvidelsen. I Norge er det fortsatt økning i tilstrømningen. I første kvartal 2006 ble det i Norge gitt 4182 tillatelser og 4024 fornyelser, mot 2735 tillatelser og 1741 fornyelser i samme periode i 2005. Ved utgangen av juni var antallet innvilgede tillatelser i 2006 steget til 24618 , hvorav om lag halvparten fornyelser, mot 16439 samme tid i 2005. Ved utgangen av juni 2006 var det 28596 gyldige tillatelser, mot 17896 på samme tidspunkt i 2005 og 11976 i 2004 (UDI 26.7.2006), det vil si mer fordobling på to år. Lenger varighet og flere fornyelser gjør at økningen i hvor mange som er i landet og jobber er langt større enn veksten i antall nye tillatelser. I Danmark er det også en kraftigere tilstrømning i 2006 enn året før. I januar-mars 2006 ble det gitt 1736 tillatelser, mot 988 i samme periode i 2005. I januar-mai ble det samlet gitt 3651 tillatelser, mens det i hele 2005 ble gitt 4923 tillatelser. Island utmerker seg med en meget kraftig vekst; i perioden januarmai 2006 ble gitt 2510 tillatelser og 1180 forlengelser, hvilket tilsvarer omtrent det totale antallet for 2005, hvor økningen også var formidabel. I Sverige er nivået stabilt og moderat, i første tertial ble det gitt 1830 tillatelser med varighet over 3 måneder. Bildet er det samme i Finland, 803 innvilgede tillatelser i første tertial tilsvarer omtrent nivået i 2005. I de to første årene etter EU-utvidelsen ble det totalt i Norden gitt 74450 arbeidstillatelser til personer fra de nye medlemslandene, samt 29949 fornyelser. En betydelig andel av tillatelsene er av kortvarig karakter, slik at nettobidraget til sysselsettingen i Norden er klart lavere enn bruttotallene i Figur 1 gir inntrykk av.

\footnotetext{
${ }^{3}$ EU Commission (2006), Report on the Functioning of the Transitional Arrangements set out in the 2003 Accession Treaty (period 1 May 2004-30 April 2006) http://eurlex.europa.eu/LexUriServ/site/en/com/2006/com2006_0048en01.doc

${ }^{4}$ Sveriges Ambassad, Dublin, Promemoria 2006-06-16.
} 


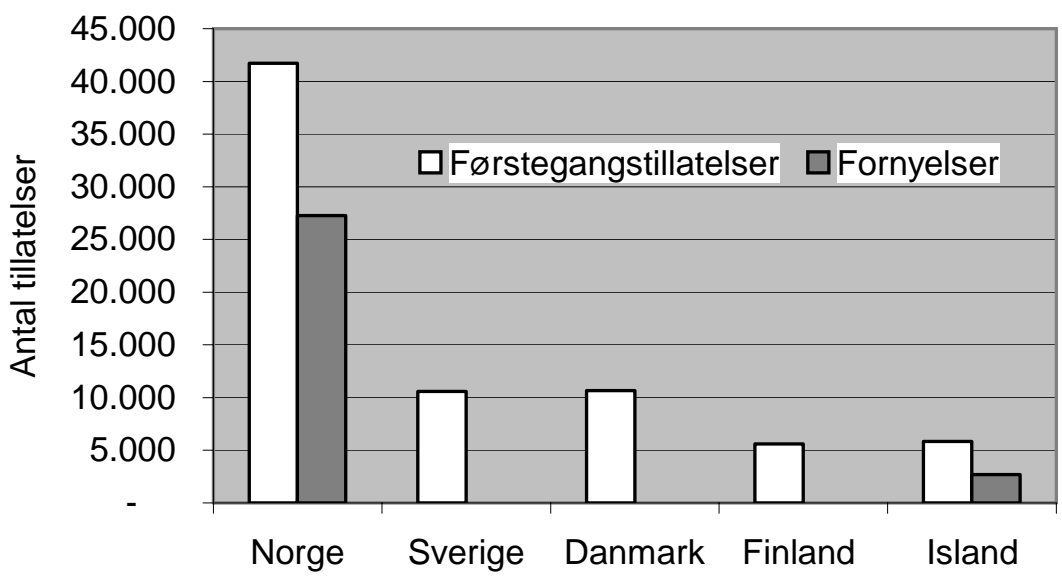

Figur 1 Arbeidstillatelser til individuelle arbeidssøkere fra EU-8 i perioden 1. mai 2004 30. april 2006, etter nordisk mottakerland (se tabell 1 i vedlegg 2 for kilder og presiseringer)

(9) Som følge av nasjonale forskjeller i registrering av tillatelser under 3 måneders varighet gir sammenlikning av totaltallene et noe fortegnet bilde. I Norge gjelder 30 prosent av tillatelsene arbeid av varighet under 3 måneder, som ikke registreres i Sverige, og bare delvis i Finland. I Finland registreres ikke sesongsarbeid innen landbruket etter 1. mai 2004, men i følge Skattestyrelsens statistikk ser det ikke ut til at antallet som kommer for sesongarbeid har økt vesentlig (før utvidelsen ble det gitt 2-3 000 slike tillatelser i året). Det finnes ikke oppdatert sammenlignbar statistikk for kun arbeidsopphold med varighet over 3 måneder, men per august 2005 stod Norge for halvparten av disse tillatelsene og andelen er økt i 2006. Selv om korttids- og sesongarbeid fortsatt utgjør en vesentlig andel av migrasjonen til Norge, er en økende andel av tillatelsene av lenger varighet. Mens 42 prosent av tillatelsene som ble gitt i januar-mai 2005 var for opphold kortere enn 3 måneder, gjaldt dette 30 prosent av tillatelsene i samme periode i 2006. 62 prosent av tillatelsene hadde varighet fra 3-12 måneder, mens andelen innvilgede tillatelser med varighet over 12 måneder utgjorde 8 prosent våren 2006. Økningen i søknader om fornyelser (fra 5526 i januar-mai 2005 til 8808 i januar-mai 2006) indikerer også en glidning mot opphold av noe lengre varighet, og overgang fra typisk sesongarbeid til annen sysselsetting som i større grad fordeler seg over hele året). ${ }^{5}$ Dette reflekteres også i et økende antall innflyttinger og familiegjenforeninger. Nettoinnflyttingen fra EU-8 i 2005 var på 4213 personer. Polen ligger nå på topp på den norske familiegjenforeningsstatistikken, og er det landet som øker mest. ${ }^{6}$ Den danske statistikken over familiegjenforeninger gjenspeiler ikke denne tendensen, her ligger

\footnotetext{
${ }^{5}$ UDI, 28.06.06, EØS-utvidelsen - tillatelser med formål arbeid. http://www.udi.no/upload/Statistikk/EOS/EOSrapport_mai2006.pps

${ }^{6}$ SSB (30.3.2006) 'Høyeste nettoinnvandring noensinne', www.ssb.no/emner/02/02/20/innvutv; UDI, Tall og fakta 1. tertial 2006 http://www.udi.no/upload/Statistikk/Tallogfakta-1tertial06.pdf
} 
Polen fortsatt langt nede på lista over familiegjenforeningssøknader. ${ }^{7}$ Sammenliknet med den totale arbeidsstyrken, utgjorde antallet utstedte oppholdstillatelser i Norden for arbeid til EU-8 borgere i 2005 (førstegangs og fornyelser) et tilskudd på om lag 0,4 prosent av den nordiske arbeidsstyrken. Tilskuddet i Norge var ca 1,6 prosent og på Island ca 2,3 prosent.

(10) Noen bransjer peker seg særlig ut som brukere av arbeidskraft fra øst; landbruk, gartneri og skogbruk (mye sesongarbeid), samt byggenceringen, men det meldes også at industrien og deler av servicesektoren (hotell, restaurant, renhold og private hushold) i økende grad rekrutterer arbeidskraft fra EU-8. Fra flere av landene mangler det imidlertid statistikk på bransjenivå. En Fafo-undersøkelse ${ }^{8}$ blant bedrifter i Norge våren 2006 viser en forholdsvis omfattende bruk av østeuropeisk arbeidskraft, både $\mathrm{i}$ form av individuelle arbeidsinnvandrere og via tjenesteyting. I byggebransjen og industrien hadde mellom 15 og 19 prosent av bedriftene brukt østeuropeisk arbeidskraft det siste året. Det samme gjaldt om lag 10 prosent av virksomhetene innen hotell/restaurant og rengjøring. Mens servicenæringene hovedsaklig rekrutterte individuelle arbeidsinnvandrere, dominerer tjenestearbeidskraften i byggebransjen og industrien. Arbeidstakere fra Polen dominerer fortsatt i Norden, særlig på Island, og i Sverige og Norge. og det kommer flere menn enn kvinner. I Finland kommer majoriteten av arbeidsinnvandrerne fra Estland, mens Danmark har omtrent like stor tilstrømning fra Baltikum som fra Polen. Det har vært antatt at ufaglert eller lavt utdannet arbeidskraft dominerer; i Danmark konkluderes det med at man kun i beskjedent omfang har lykkes i å rekruttere faglært og høyere utdannet arbeidskraft fra de nye EUlandene. ${ }^{9}$ I Finland har man registrert en betydelig økning i mobiliteten av helsepersonell østfra, særlig fra Estland, men fordi tillatelsene oftest er gitt utenfor overgangsordningenes tillempingsområde, framkommer de i liten grad i den ordinære statistikken. I perioden 1. mai 2004-desember 2005 registrerte for eksempel Rättsskyddcentralen för hälsovården 432 leger og tannleger fra EU-8, hvilket i denne sammenhengen ikke er et lite antall. Men også i den finske statistikken er yrker som krever lav eller ingen utdanning dominerende. ${ }^{10}$ I Norge tyder resultatene fra Fafos undersøkelse på mer bruk av faglært østeuropeisk arbeidskraft enn det man tidligere har antatt, men det er fortsatt svært få bedrifter som har rekruttert høyt kvalifisert arbeidskraft fra øst.

(11) De markante forskjellene i tilstrømningen av individuelle arbeidssøkere til de nordiske landene er ikke enkle å forklare, også fordi det ikke

\footnotetext{
${ }^{7}$ Udlændingestyrelsen juni 2006, Familiesammenføringsansøgningsantal.

${ }^{8}$ Dølvik, J.E., L. Eldring, J.H. Friberg, T. Kvinge, S. Aslesen og A.M. Ødegård (2006), EUutvidelsen: Endringer i norske bedrifters arbeidskraftsstrategier? Fafo-notat 2006:14

${ }^{9}$ Arbejdsmarkedsstyrelsen, Notat. Bilag til møte i forligskredsen den 5. april 2006

${ }^{10}$ Statsrådets redogörelse til riksdagen om verkningarna av lagen om övergangstid samt verkningarna av arbetskraftens och tänesterna fria rörlighet på arbetsmarknadsläget inom olika brancher. Finland, 2006.
} 
foreligger sammenliknbar informasjon om hvor store arbeidsvandringer som skjer i form av andre typer mobilitet, spesielt tjenestevandringer. Ulikheter i etterspørselen etter arbeidskraft spiller utvilsomt en svært viktig rolle (jevnfør den beskjedne migrasjonen til Sverige, og forskjellene mellom Danmark og Norge). Overgangsordningene kan bare forklare noe av variasjonene. Sverige har som kjent ingen overgangsordning og omfanget av korttidsarbeid under 3 måneder er derfor ukjent. Danmark og Norge har hatt langt mer liberal ordninger enn Finland og Island. Alle overgangsordningene har stilt krav om «nasjonale lønnsvilkår og heltidsarbeid). Finland og Island vurderte i tillegg behovet for arbeidskraft, hvilket trolig har bidratt til å redusere pågangen av søkere. Ettersom overgangsordningene i Danmark og Norge i hovedsak er sammenliknbare, kan årsaken til de markante forskjellene ikke ligge i selve kriteriene for å få tillatelse - de må ligge på etterspørselssiden og/eller i selve utøvelsen av adgangsprøvingen og signaleffektene av denne på søkertilgangen. Danmarks profilerte «Østavtale» og mer systematiske håndtering av søknader og kontroll kan ha bidratt til at det danske regimet er blitt oppfattet som striktere enn det norske. I tillegg har nok den kraftige oppgangen i det norske arbeidsmarkedet, samt etablerte nettverk gjennom økende sesongmigrasjon siden 90-årene og relativt høyt lønnsnivå for ufaglært arbeid, bidratt til den raske veksten i arbeidsmigrasjonen til Norge. De nordiske erfaringene tyder altså på at tilstrømningen er etterspørselsensitiv, og ingen land rapporterer om «sosial turisme» som var et fremtredende tema i debattene forut for EU-utvidelsen.

Status for overgangsordningene etter 1. mai 2006

(12) De nordiske landene valgte i 2004 ulike tilpasninger til EUutvidelsen, og reflekterte slik sett det europeiske bildet som varierte mellom 1) restriktive overgangsregimer med kvoter og arbeidsmarkedsprøving (Belgia, Finland, Frankrike, Tyskland, Hellas, Island, Luxembourg, Spania, Østerrike, Italia, Nederland, Portugal), 2) regimer som åpnet for arbeidsinnvandring, men med spesifikke krav til arbeids- og lønnsvilkår (Danmark, Norge) 3) og land som valgte full liberalisering og åpning av arbeidsmarkedet (Irland, Storbritannia, Sverige, (dog med registreringsordninger i Irland og Storbritannia)). 
Figur 2 Overgangsordninger i EU-15 før og etter 1. mai $2006^{11}$

Etter 1. mai 2006 har det i Europa skjedd en betydelig bevegelse fra gruppe (1) til gruppe (3) - som blant de nordiske landene. I tillegg til Finland og Island, har også Portugal, Spania, Hellas og nylig Italia opphevet restriksjonene for arbeidstakere fra EU-8. Interessant nok er gruppe (2) med Danmark og Norge den eneste som er uforandret. Erfaringen i hele Europa har vært at overgangsordningene har hatt begrenset effekt dersom intensjonen var å demme opp og kontrollere tilflyten av arbeidskraft, i og med at tjenestemarkedet åpnet for fullt med en gang (med unntak av Tyskland og Østerrike som hadde anledning til også å innføre overgangsregler for tjenestemobilitet). På den andre siden har den ordinære arbeidsinnvandringen vært forholdsvis lav til mange av disse landene, og faktisk lavere enn ønsket i en del tilfeller. De nasjonale debattene har følgelig endret karakter de siste par årene; fra en utstrakt bekymring for å bli oversvømt av østeuropeere som ønsker å utnytte vestlige velferdsordninger, har oppmerksomheten blitt vendt mot arbeidskraftknapphet og ikke minst konkurransen om kompetent arbeidskraft. Når en i tillegg har sett at de største problemene knyttet til lavlønnskonkurranse og sosial dumping har oppstått i tjenestemarkedet, er det ikke overraskende at en del land har beveget seg fra restriktive til liberale løsninger. Kommisjonen, og partene på europeisk plan, anbefalte også oppheving av overgangsordningene, og de fleste land har signalisert en gradvis utfasing fram mot 2009.

(13) I Sverige har myndighetene og partene tatt den beskjedne tilstrømningen som bekreftelse på at det var en riktig beslutning å ikke innføre overgangsordning. Partene fremhever at tidligere ulovlig arbeid er

\footnotetext{
${ }^{11}$ Dølvik, Jon Erik og Line Eldring (2006), Industrial relations responses to migration and posting of workers after EU enlargement: Nordic trends and differences. I: Transfer- European Review of Labour and Research 2/2006. Se også: Transitional measures for the free movement of the workers forming the subject of the accession treaty of 2003, Memo/06/176: http://www.europa.eu.int/rapid/pressReleasesAction.do?reference=MEMO/06/176\&format=HTML\& aged $=0$ \&language $=E N \&$ guiLanguage $=$ no
} 
blitt legalisert, og selv om man har liten oversikt over korttidsmarkedet (under 3 måneder) pekes det på at den høye avtaledekningen i hovedsak sikrer <ordning och reda) og at veksten i tjenestemobiliteten synes lavere enn i de nordiske landene med overgangsordning for individuelle arbeidstakere.

(14) I Finland ble det alt tidlig i den første toårsperioden uttrykt bekymring over at barrierene mot individuell arbeidsmigrasjon førte til markant voksende tjenestemobilitet med til dels irregulære arbeidsforhold. Veksten i tjenestemobiliteten gjorde overvåkingen av arbeidsvilkårene vanskeligere, og det viste seg problematisk å holde oversikt over hvor mange som har kommet. Partene og regjeringen ble våren 2006 enige om at overgangsordningen ikke burde videreføres, med særlig henvisning til at den har hindret at arbeidskraften blir ansatt hos finske arbeidsgivere. I Statsrådets vurdering av virkningene av overgangsloven vektlegges de uheldige vridningseffektene, og at en oppheving av restriksjonene for individuell arbeidsinnvandring kan medvirke til å dempe dette. Finland vedtok derfor å oppheve overgangsordningene, samtidig som det ble utarbeidet lovforslag om registrering av opplysninger om arbeid som utføres av arbeidstakere fra EU-8, en ny lov om bestilleransvar, samt vedtatt en skjerping av utstasjoneringsloven. Intensjonen er at et nytt og forsterket lovverk skal bidra til å sikre akseptable arbeids- og lønnsvilkår, på en mer effektiv måte enn gjennom overgangsordningene som bare gjaldt deler av arbeidsmarkedet. Den førstnevnte loven trådte i kraft 5. juni 2006, og gjelder til og med 30. april 2009. Loven om registrering påbyr at visse opplysninger om arbeidet oppgis til arbeidsmarkedsmyndighetene (arbetskraftbyrån) senest 14 dager etter arbeidets påbegynnelse. Opplysningene kan oppgis av arbeidsgiveren, eller arbeidstakeren selv. Det skal opplyses om arbeidstakers personalia, arbeidsgivers foretaks- og organisasjonsnummer, bransje, arbeidssted, arbeidets varighet, hvilken kollektivavtale som gjelder, eller hvilken lønn som betales. Ved skifte av arbeidsgiver eller andre vesentlige endringer, skal nye opplysninger gis.

(15) Island har for tiden et stort behov for arbeidskraft, og det ble registrert en sterk vekst i tilstrømningen av arbeidsinnvandrere fra EU-8 i 2005. Den islandske regjeringen vedtok derfor, med tilslutning fra partene, å ikke forlenge arbeidsmarkedsrestriksjonene for personer fra de nye EU-landene. Fra og med 1. mai 2006 kan arbeidstakere fra de nye medlemslandene dermed fritt søke om arbeid og bli ansatt uten arbeidstillatelse. Fram til 1. mai 2009 må imidlertid arbeidsgiverne innen 10 dager informere Arbeidsdirektoratet om at de har ansatt en person fra EU-8 og de må legge ved en kopi av arbeidskontrakten. Arbeidsgivere som ikke oppfyller dette kravet risikerer bøter. Formålet med registreringen er å overvåke at ansettelsesvilkårene er i tråd med gjeldende avtaler og regler, samt å gi en mulighet for myndighetene til å informere arbeidstakerne om deres rettigheter. Berørte fagforbund har rett til å få kopi av utenlandske arbeidstakeres arbeidskontrakter dersom de mistenker brudd i forhold til 
gjeldende kollektivavtale. I forbindelse med opphevingen av overgangsordningene ble det nedsatt en arbeidsgruppe med representanter fra partene og regjeringen for å utrede situasjonen for utlendinger i det islandske arbeidsmarkedet, inkludert tjenestemarkedet.

(16) I Danmark er det enighet om at overgangsregimet har virket etter hensikten og har medvirket til ordentlige vilkår for arbeidsinnvandrerne. Vurderingen er at overgangsordningen har gitt viktige signaler om at arbeid i Danmark bør foregå på «danske vilkår», og at den har bidratt positivt til å opprettholde en bred politisk og folkelig oppslutning om EUutvidelsen. Analyser av EU-utvidelsens betydning for det danske arbeidsmarkedet konkluderte med at det verken var oppstått ubalanser i arbeidsmarkedet eller utilsiktet bruk av sosiale ytelser. Selv om tilstrømningen har vært for lav til helt å hindre flaskehalser, vurderes det at arbeidsmigrasjonen har hatt en positiv innvirkning på arbeidsmarkedstilpasningen, ikke minst knyttet til sesongarbeidet i landbruket. Man har i liten grad lykkes med å rekruttere faglært arbeidskraft. Også i lys av den høye temperaturen i dansk økonomi, er målsettingen framover å styrke rekrutteringen av arbeidstakere fra EU-8. Danmark valgte derfor å justere overgangsordningen og å revidere den tidligere inngåtte Østavtalen, for å sikre en mer smidig og fleksibel rekruttering av nødvendig arbeidskraft, samtidig som kravet om at arbeidstakere fra EU-8 skal ansettes på overenskomstmessige vilkår opprettholdes. Ett sentralt punkt i den reviderte overgangsordningen er at virksomheter som er omfattet av kollektivavtale kan forhåndsgodkjennes til å ansette arbeidstakere fra EU-8. Arbeidstakere som ansettes i disse bedriftene trenger dermed ikke oppholds- og arbeidstillatelse i forkant av ansettelsen, men det skal meldes fra om ansettelsesforholdet til utlendingsmyndighetene i det vedkommende begynner å arbeide. Det gis videre større muligheter for pendling, deltidsarbeid, automatisk arbeidstillatelse for studenter fra EU-8 og rett til å arbeide mens søknad om forlenget tillatelse behandles - og det er et mål at alle saksbehandlingstider skal reduseres. Samtidig skal ulike tiltak settes i verk for å stimulere rekrutteringen av nødvendig arbeidskraft. Det skal løpende vurderes i 3-årsperioden om det er behov for ytterligere revisjon av overgangsreglene, og partene i Østavtalen skal møtes halvårlig for å vurdere om man bør oppheve kravet om oppholdstillatelse i bransjer med særlige behov for arbeidskraft.

(17) Norge valgte å videreføre overgangsordningen uten endringer. Den relativt store tilstrømningen av arbeidstakere fra EU-8 ble tatt som et tegn på at overgangsordningen i liten grad har hemmet rekrutteringen av arbeidskraft. Den norske regjeringen oppsummerte våren 2006 at EUutvidelsen har tilført det norske arbeidsmarkedet høyst nødvendig arbeidskraft, og at arbeidskraftsbehovet vil øke ytterligere de neste årene. ${ }^{12}$ På tross av en viss bekymring for at fortsatte overgangsordninger kan

\footnotetext{
landa.

${ }^{12}$ Stortingsmelding 9 (2005-2006), Om overgangsordningane for arbeidstakarar frå dei nye EØS-
} 
virke dempende på rekruttering av arbeidskraft til Norge - særlig når andre land opphever ordningene - foreslo regjeringen å forlenge overgangsordningene i sin nåværende form, hvilket også ble vedtatt i Stortinget. Hovedbegrunnelsen var at overgangsordningen bidrar til å sikre ryddige forhold i arbeidsmarkedet, og at en før utfasing må ha på plass forsterket regelverk og tiltak for å forhindre sosial dumping. Det understrekes at ordningene kan oppheves i løpet av treårsperioden, og at det vil bli foretatt en ny vurdering i løpet av perioden. Det har vært omdiskutert hva slags effekt overgangsordningen har hatt i forhold til beskyttelse av lønns- og arbeidsvilkår. Blant annet viste Fafos bedriftsundersøkelse at en betydelig andel av virksomhetene som bruker individuell arbeidskraft oppgir å ha redusert lønnskostnadene og økt arbeidstidsfleksibiliteten. Den siste tiden er det også rapportert om en oppblomstring av enmannsfirma for å omgå overgangsbestemmelsene og allmenngjøringene i byggebransjen. I forbindelse med forlengelsen av overgangsordningene lanserte regjeringen en tiltakspakke mot sosial dumping. Blant tiltakene som lanseres er forsterking av tilsynsvirksomhetene, både i form av ressurser, økt samarbeid mellom etater og utvidede sanksjonsmuligheter dersom allmenngjorte tariffavtaler eller overgangsordningene ikke overholdes. Videre skal det arbeides med innføring av ID-kort i byggebransjen, gjennomføring av ILO 94-konvensjonen også i kommunal sektor og sikre ryddigere forhold ved inn- og utleie av arbeidskraft.

(18) Uavhengig av hva de vestlige EU/EØS-landene har valgt i 2006 når det gjelder overgangsordninger, står de overfor den samme utfordringen i 2009; da skal det gjelde like regler for alle landene som per i dag er EU/EØS-medlemmer. Når det gjelder Bulgaria og Romania, som etter planen innlemmes i unionen 1. januar 2007, har det kommet litt ulike signaler med hensyn til om man vil innføre restriksjoner. Selv noen av de «nye» EU-landene har antydet at det kan være aktuelt med overgangsregler for Bulgaria og Romania. Dette kan virke paradoksalt, med tanke på de sterke negative reaksjonene på overgangsregimene som har omfattet dem selv, men må tolkes som et uttrykk for den uroen flere av nabolandene har i forhold til innlemmelsen av nye land med høy ledighet, svak økonomi og en betydelig uformell sektor.

Danmark og Norge, valgte en mellomløsning i 2004, og holder inntil videre den samme kursen. Når det gjelder ordningenes hensiktsmessighet i forhold til å sikre ordnede forhold, synes det som om fraværet av et dekkende minstelønnsregime har gjort at det framstår som tryggest fortsatt å benytte muligheten til å stille bestemte krav om lønns- og arbeidsvilkår for individuelle arbeidsinnvandrere. Det gjør ikke utfordringen med å utvikle lov- og avtaleverk som kan virke for alle arbeidskraftgrupper - særlig for Norges del - noe mindre, men aktørene vinner noe mer tid. Mens Finland og Island har lange tradisjoner for allmenngjøring av tariffavtaler, synes dette fortsatt uaktuelt i Danmark, og er med unntak av byggenæringen, lite brukt i Norge. Sveriges svært høye kollektivavta- 
ledekning og fagbevegelsens virkemidler når det gjelder sympatiaksjoner og boikott, ser så langt ut til å ha gitt god effekt når det gjelder å oppfylle intensjonen om «svenske vilkår». I Danmark og Norge har altså overgangsordningenes «allmenngjøringsbestemmelser» for EU-8-borgere vært sentrale i vurderingene av om overgangsordningene skulle videreføres. I bransjer med lav organisasjons- og avtaledekning, som servicenæringene og landbruket, er det grunn til å tro at potensialet for press mot lavere lønninger vil kunne være betydelig dersom tilbudet av arbeidskraft fortsatt øker. Allerede i dag kan vi anta at det foregår omgåelser av overgangsordningenes bestemmelser, og tilsyn- og kontrollressursene er begrenset. Dette gjelder særlig i Norge, hvor omfanget av innvandringen har vært størst. For alle landene gjelder det at vi vet lite om hvordan arbeidsinnvandrerne faktisk har det. Ved utfasing av overgangsordningene vil uansett kravet om nasjonale lønnsvilkår falle bort. Alle landene har lovfestet vern mot diskriminering, som i prinsippet skal beskytte utenlandske arbeidstakere mot lønnsdiskriminering i forhold til andre arbeidstakere i samme bedrift. Dette vil imidlertid neppe ha særlig effekt dersom vi får en forsterket utvikling av bedrifter i enkelte bransjer som «spesialiserer seg〉 på bruk av lavtlønnet utenlandsk arbeidskraft. Dersom alle tjener like dårlig, diskrimineres for så vidt ingen, men arbeidsmarkedseffektene i de aktuelle bransjene kan likevel bli merkbare.

(19) Den nordiske debatten rundt arbeidsinnvandring har naturlig nok først og fremst vært konsentrert om situasjonen i mottakerlandene, og mindre om konsekvenser i avsenderlandene. Både i Norden og Europa for øvrig er det en tiltakende bekymring for mangel på arbeidskraft $\mathrm{i}$ årene framover - og dette gjelder også de i nye medlemsstatene, på tross av betydelig ledighet i en del regioner per i dag. I Norden, og særlig Norge, har den økte tilgangen på arbeidskraft smurt en økonomi på høygir, og det meldes om akutt behov for arbeidskraft i mange bransjer. Det er også en kamp om kompetansen i Europa, og mens man i vest diskuterer hvordan en skal trekke til seg høykvalifisert arbeidskraft fra øst, bekymrer man seg i øst for brain-drain og kompetansetørke. I følge polske myndigheter arbeider nå rundt 1 million polakker i andre EU/EØS-land og forskere mener tallet er rundt 2 millioner. I et slikt perspektiv er det på lengre sikt vanskelig å se for seg at det vil være en bærekraftig strategi for de nordiske landene å satse på at arbeidskraftstilgangen kan sikres ved ekstern tilgang av kompetanse fra EU-8, både i kvalitativ og kvantitativ forstand. Erfaringene fra det intra-nordiske arbeidsmarkedet har vist at både etterspørsel og tilbud er sterkt konjunkturavhengig, og dermed svært skiftende. I et slikt perspektiv tilsier de strukturelle arbeidskraftsutfordringene i Norden og Europa at det er behov for en mer helhetlig og langsiktig politikk for økt arbeidskraftstilgang, som kombinerer intern mobilisering av ubrukte arbeidskraftsressurser med en målrettet politikk for å trekke til seg internasjonal kompetanse også fra land utenfor EU-8. 


\section{2. Økende tjenestemobilitet og utstasjonering av arbeidstakere}

(20) Den frie bevegelsen av tjenester er knesatt i EUs traktater (artikkel 49) så vel som i EØS-avtalen (artikkel 36), og er ikke omfattet av overgangsordningene i forbindelse med EU-utvidelsen. Trass i mangelfull statistikk rapporterer alle de nordiske land om markant vekst i tjenestemobilitet fra EU-8 og at denne i enkelte sektorer - f.eks. bygning og industri - sannsynligvis overstiger den ordinære arbeidsmigrasjonen. I Norge har skattemyndighetene rapportert en tredobling av registrerte utstasjoneringer hvert år siden 2004, og i byggebransjen og industrien viser en Fafo-studie at det er langt flere utstasjonerte enn direkteansatte arbeidstakere fra EU-8 (Dølvik mfl 2006). Veksten i tjenestemobilitet har hatt positive virkninger for økonomien og bidratt til å løse opp flaskehalser, men har i deler av arbeidsmarkedet også skapt problemer med sosial dumping, lavlønnskonkurranse, omgåelse av lov- og avtaleverk og skatteunndragelser. En del underentreprenører og enkeltmannsfirma utøver virksomhet som i realiteten synes å dreie seg om rettstridig formidling av ordinær arbeidskraft («fiktiv utstasjonering)). Samtidig som den økende tjenestemobiliteten reiser nye utfordringer når det gjelder regulering, registrering, kontroll, håndheving og sanksjoner, bidrar den til endringer i bedrifters arbeidskraftsstrategier som kan påvirke deler av arbeidsmarkedets virkemåte.

(21) Utenlandske tjenesteleverandører skal i henhold til EU-retten likebehandles med vertslandets aktører og kan fritt medbringe egen arbeidskraft for å utføre oppdrag. Tjenester omfatter i denne sammenheng også alle typer anbud, oppdrag og underentrepriser, samt arbeidsutleie og formidling av vikarer, ${ }^{13}$ og har dermed nær sammenheng med - og er ikke alltid lett å skille fra - bevegelse av arbeidskraft. Grenseoppgangen mellom fri bevegelse, vern av arbeidstakere og beskyttelse av vertslandets arbeidslivsstandarder mot sosial dumping er trukket opp i EUs Rådsdirektiv 96/71/EF om utsending av arbeidstakere i forbindelse med tjenesteyting (uutstasjonerings-direktivet). ${ }^{14}$ Direktivet legger vertslandsprinsippet til grunn når det gjelder lønns- og arbeidsvilkår, men fastslår at vertslandets krav til lønns- og arbeidsvilkår i tråd med likebehandlings-

\footnotetext{
${ }^{13}$ I transportsektoren er det en overgangsordning for såkalt kabotasje som innebærer en utsettelse (4-6 år) av retten for transportselskaper fra de nye EU-landene til å utføre innenlandske transportoppdrag.

${ }^{14}$ For en oversikt over regler og nasjonal praksis når det gjelder utstasjonering av arbeidstakere $\mathrm{i}$ det indre marked, se Bruun (2006), Cremers (2006), Dølvik og Eldring (2006), Maier (2005), samt temanummer av Transfer 2/2006 Mobility of Labour and Services in an Enlarged Europe.
} 
prinsippet også må gjelde nasjonale arbeidstakere og følgelig må være nedfelt i lovfestet minstelønn, allmenngjorte tariffavtaler eller allment gyldige tariffavtaler (artikkel 3.8). Utstasjonerte arbeidstakere omfattes ikke av vertslandets trygde- og velferdsordninger (Forordning 1408/71) og skal betale skatt og trygdeavgifter til hjemlandet det første $1 / 2-1$ år. Utenlandske tjenestefirma skal betale moms (VAT) i vertslandet på linje med nasjonale virksomheter. Utstasjoneringsdirektivet regulerer ikke vilkårene for vertslandskontroll av lønns- og arbeidsvilkår, men EFdomstolen har i sin rettspraksis trukket opp kriterier for hvordan vertslandets krav (ut fra hensyn til allmenne interesser) kan praktiseres, basert på prinsippene om likebehandling, gjensidig godkjenning og proporsjonalitet. ${ }^{15}$ EUs nåværende forslag til tjenestedirektiv rokker ikke ved disse hovedprinsippene, men Kommisjonens arbeid med å evaluere/følge opp implementeringen av utstasjoneringsdirektivet kan bidra til en klargjøring - og muligvis skjerping - av vilkårene for vertslandskontroll (Commission report January 2003; COM(2006)159 final).

(22) Ettersom ingen av de nordiske land har lovfestete minstelønnsordninger og allmenngjøring av tariffavtaler bare praktiseres i Finland, Island og delvis i Norge, har veksten i tjenestemobilitet fra EU-8 utfordret de nordiske tradisjonene for regulering, kontroll og håndheving av lønns- og arbeidsvilkår i arbeidsmarkedet. Dette er blitt satt på spissen i Laval/Vaxholm-saken som nå er til behandling i EF-domstolen, ${ }^{16}$ og har utløst fornyet debatt om de nordiske landenes implementering av EUs utstasjoneringsdirektiv. I likhet med Island har Finland det siste året gått langt i å lovfeste et avtalebasert minstelønnsregime for utstasjonert arbeidskraft. Sverige og Danmark bygger på den autonome avtalemodellen hvor fagforeningene, om nødvendig ved hjelp av boikott og sympatiaksjoner, presser utenlandske tjenestefirma til å inngå tariffavtale i tråd med nasjonale vilkår. Lavere tariffavtaledekning, samt skranker i lov og avtaleverket, gjør at slike strategier i praksis ikke er realistiske i Norge, hvor fagforeningene i byggebransjen derfor har stilt krav om landsomfattende allmenngjøring av minstestandardene i byggfagsoverenskomsten. De nordiske land har altså svært ulike vilkår og virkemidler for å motvirke forskjellsbehandling og sosial dumping og dermed opprettholde et effektivt minstelønnsnivå i de nasjonale arbeidsmarkedene. Utfasingen av overgangsordningene - som hittil har hatt en «ad hoc > allmenngjøringsfunksjon overfor EU-8 arbeidstakere - kan, som nevnt over, øke utfordringene på dette feltet.

\footnotetext{
${ }^{15}$ Se for eksempel Maier, Lena (2005), Utstationering av arbetstagare och det svenska kollektivavtalssystemet. En rättslig analys. Stockholm: SACO, Bruun, Niklas (2006), Posting of workers: do the EU-rule work? A Nordic perspective. Mini-hearing, Europan Parliament, 20.04.2006 eller Evju, Stein (2006), Evaluering av allmenngjøringsordningen - høring. http://odin.dep.no/filarkiv/269805/Evju.pdf

${ }^{16}$ Se Ahlberg, Bruun og Malmberg (2006) i Transfer 2006/2, og Sveriges saksframlegg til EFdomstolen; Regeringskansliet, Utrikesdepartementet, 2006-01-30.
} 
(23) Uavhengig av reguleringsform viser erfaringene de to første årene at sikring av et effektivt lønnsgolv og likebehandling i de ulike arbeidsmarkedene er meget krevende når det gjelder kontroll og håndheving. Enten det er Arbeidstilsynet eller fagforeningene, eventuelt i samarbeid med arbeidsgiverne, som skal ivareta disse funksjonene, er oppgavene svært arbeids-og kompetansekrevende, samtidig som de ofte er forbundet med vanskelige rettslige grenseoppganger både når det gjelder nasjonale lovhjemler, sanksjoner, og forholdet til EU-retten. I praksis reiser dette uansett reguleringsregime nye krav til samarbeid mellom ulike myndighetsinstanser, bedrifter og partene i arbeidslivet. For å skaffe informasjon om bevegelsene og aktørene i markedene må landene kombinere ulike indirekte kilder knyttet til ervervsregistre, skatte- og trygdeetatene og samarbeide med avsenderlandenes myndigheter. Samtidig som EU/EØS-reglene for fri bevegelse gir viktige rammebetingelser for registrering, innsyn og kontroll av ansatte hos utenlandske tjenesteytere, er dette regimet nå under omprøving $\mathrm{i}$ forbindelse med evalueringen av utstasjoneringsdirektivet og gjennomføringen av tjenestedirektivet. Ved siden av innenlandske utfordringer knyttet til videreutvikling/tilpasning av de interne regulerings- og kontrollregimene i takt med at den ytre kontrollen med arbeidsmarkedet opphører, er det følgelig en besøkelsestid for de nordiske landene når det gjelder å påvirke den politiske og rettslige utviklingen på feltet på EU-nivå i tråd med nordiske mål og interesser. I disse prosessene vil landene trolig ha mye å vinne på å lære av hverandres tiltak og erfaringer, og å samordne arbeidet overfor EU. I de etterfølgende punktene vil vi derfor gi en oversikt over de viktigste temaene og problemstillingene på agendaen i disse prosessene.

\subsection{Regulering av lønns- og arbeidsvilkår for utstasjonerte arbeidstakere}

(24) Som det fremgår av oversikten nedenfor har de nordiske landene implementert utstasjoneringsdirektivet (Dir71/96EC) svært forskjellig og de nasjonale lov- og avtalesystemene gir ulike virkemidler for å stille og håndheve krav om «nasjonale lønnsvilkår» for utenlandske arbeidstakere (se Bruun 2006). Dette avspeiler forskjeller mellom landene når det gjelder organisasjons- og avtaledekning (se figurer neste side), samt i synet på statens rolle i forhold til lønnsdannelsen, minstelønnsregulering og allmenngjøring. I alle landene, bortsett fra Norge, er inngåtte tariffavtaler bindende for alle medlemsbedrifter i den aktuelle arbeidsgiverorganisasjonen. 


\begin{tabular}{|c|c|c|c|c|c|}
\hline & Danmark & Finland & Island & Norge & Sverige \\
\hline $\begin{array}{l}\text { Lønn individuelle } \\
\text { arbeidsinnvandrere } \\
\text { fra EU-8 } 8^{17}\end{array}$ & $\begin{array}{l}77 \% \text { avtaledekning } \\
\text { i privat sektor } \\
\text { Til 2009: } \\
\text { Overgangsordning; } \\
\text { «danske vilkår» }\end{array}$ & $\begin{array}{l}90 \% \text { avtaledekning } \\
\text { (offentlig og privat) } \\
\text { Utbredt allmenngjø- } \\
\text { ring }\end{array}$ & $\begin{array}{l}90 \% \text { avtaledekning } \\
\text { (offentlig og privat) } \\
\text { Lovgivning sikrer } \\
\text { minst avtalefestet } \\
\text { minstelønn }\end{array}$ & $\begin{array}{l}53 \% \text { avtaledekning } \\
\text { privat sektor } \\
\text { Til 2009: Over- } \\
\text { gangsordning; } \\
\text { «norske vilkår» } \\
\text { Allmenngjøring } \\
\text { (vesentlig i bygg- } \\
\text { fag) }\end{array}$ & $\begin{array}{l}90 \% \text { avtaledekning } \\
\text { privat sektor }\end{array}$ \\
\hline $\begin{array}{l}\text { Lønn utstasjonerte } \\
\text { fra EU/EøS }\end{array}$ & $\begin{array}{l}\text { Tiltrædelsesavtaler } \\
\text { med lokale for- } \\
\text { handlinger, eller } \\
\text { innmelding i ar- } \\
\text { beidsgiverorg som } \\
\text { gjør dennes avtale } \\
\text { bindende }\end{array}$ & $\begin{array}{l}\text { Allmenngjøring } \\
\text { Utstasjoneringslo- } \\
\text { vens krav om } \\
\text { tarifflønn }\end{array}$ & $\begin{array}{l}\text { Allmenngjøring } \\
\text { Utstasjoneringslo- } \\
\text { vens krav om } \\
\text { tarifflønn }\end{array}$ & $\begin{array}{l}\text { Hjemlandsvilkår } \\
\text { hvis ikke allmenn- } \\
\text { gjøring (vesentlig i } \\
\text { byggfag) }\end{array}$ & $\begin{array}{l}\text { Hengeavtaler } \\
\text { Lex Britannia }\end{array}$ \\
\hline
\end{tabular}

Figur 3 Regulering av lønn og arbeidsvilkår for arbeidstakere fra EU-8 i Norden

(25) Island har siden tidlig i 80-årene hatt lovgivning som knesetter at alle lønnstakere minst skal ha lønn i tråd med minstelønnssatsene i den relevante tariffavtale, uten at dette har påvirket medlemstilgangen i fagforeningene. Finland har siden tidlig i 70-årene hatt en lov om allmenngjøring av landsomfattende tariffavtaler, og innførte i 2006 en bestemmelse i utstasjoneringsloven som skal sikre utstasjonerte arbeidstakere som ikke er omfattet av allmenngjort avtale lønn i tråd med den mest relevante tariffavtalen. Begge landene har altså et lovbasert, EU-konformt system, hvor minstesatsene i tariffavtalene definerer et lønnsgolv i arbeidsmarkedet. Systemet virker uomstridt blant de sosiale partene og sikrer i teorien mot uønsket konkurransevridning i arbeidsmarkedene.

(26) I Sverige og Danmark er det bred enighet blant de sosiale partene om doktrinen at lønnsspørsmål er en sak for arbeidsmarkedets parter alene. Lovgivning i lønnsrelaterte spørsmål blir sett som en trussel mot avtalesystemet og på sikt mot oppslutningen om organisasjonene. Landene unnlot derfor også å benytte Artikkel 3.8 i utstasjoneringsdirektivet, som åpner for statlig implementering av vertslandsprinsippet ved å vise til tariffavtaler som er allment gyldige i de aktuelle yrker/bransjer eller regioner. I praksis er det dermed fagforeningene som har ansvaret for å sikre at utstasjonerte arbeidstakere godtgjøres i tråd med nasjonalt lønnsnivå. Dette gjennomføres ved å spore opp utenlandske arbeidsgivere og overbevise dem - om nødvendig med boikott og sympatiaksjoner - om å melde seg inn i arbeidsgiverforeningen og tiltre deres avtale, eller inngå en hengeavtale (svensk) eller tiltrædelsesavtale (dansk). I Danmark er det legalt å bruke stridsmidler for å presse bedrifter med en allerede eksisterende (konkurrerende) avtale til å inngå en ny overenskomst. I henhold til den svenske Medbestämmandelagen (MBL) er bruk av stridsmidler i slike tilfelle forbudt overfor svenske bedrifter, men i henhold til den sk.

\footnotetext{
${ }^{17}$ Tall på tariffavtaledekning i privat sektor er hentet fra: Lismoen, H. (2006), Low-wage regulation in Scandinavia. I: Schulten, T. et al (ed.), Minimum wages in Europe. Brussels: ETUI-REHS og http://www.ilo.org/travaildatabase/servlet/minimumwages
} 
Lex Britannia-klausulen gjelder dette ikke overfor bedrifter som ikke er bundet av MBL, dvs utenlandske bedrifter. I Laval/Vaxholm-saken har de lettiske partene hevdet at dette er diskriminerende, mens Sverige ser det som et nødvendig og proporsjonalt tiltak for å innfri direktivets formål som er å sikre utenlandske arbeidstakere like vilkår i Sverige (Utrikesdepartementet 2006-01-30) ). I fall Laval/Vaxholm-saken ikke går Sveriges vei, er det fra svensk forskerhold påpekt at likebehandlingsprinsippet kan innfris ved relativt beskjedne justeringer i MBLs Lex Britannia- og Britannia-klausuler (Ahlberg mfl 2006). For å motvirke problemene for utenlandske tjenesteytere har de sentrale svenske partene også inngått en rammeavtale som tilbyr utenlandske firma en «tilpasset pakke〉 med garanti for arbeidsfred under lønnsforhandlinger hvis de melder seg inn i den relevante arbeidsgiverorganisasjonen og dermed tiltrer en tillempet utgave av bransjeavtalen. Svenske bransjeavtaler forutsetter, i likhet med danske avtaler, lokale forhandlinger om den faktiske lønnsfastsettelsen. Rammeavtalen sikrer fagforeningene innsyn i lønns- og arbeidsvilkår. I den grad utenlandske tjenestefirma benytter 〈pakken〉 vil dette kunne innebære at partene langt på vei har funnet en avtalebasert løsning på Laval/Vaxholmknuten.

(27) Norge befinner seg i en mellomstilling i Norden på dette feltet. Lavere organisasjonsgrad og avtaledekning, samt lov- og avtalefestete skranker mot stridstiltak, gjør at svensk/danske strategier er lite realistiske. Samtidig er partene generelt skeptiske til statlig regulering av lønnspørsmål og dermed også overfor omfattende allmenngjøring. I all hovedsak har det derfor vært helt legalt og sedvanlig praksis å hyre EØSunderentreprenører med arbeidskraft som godtgjøres ut fra hjemlandets standarder som gjerne ligger langt under gjengs norsk nivå. Allmenngjøringsloven av 1994 har et avgrenset formål som er å motvirke forskjellsbehandling av utenlandske arbeidstakere og kan vanligvis bare tas i bruk i etterhånd. Hvis det foreligger tilstrekkelige bevis kan et flertall i Tariffnemnda (som har 3 nøytrale medlemmer og en fra hver av arbeidslivets parter) etter skjønn vedta hvilke vilkår og bestemmelser i tariffavtalen som skal gjøres allment gjeldende. Hittil har dette hovedsakelig skjedd på regional basis i byggebransjen, men her er det nå også reist krav om landsomfattende allmenngjøring. I kontrast til det finske og islandske allmenngjøringsinstituttet, som er en del av det ordinære nasjonale reguleringsregimet og settes i kraft etter forutsigbare og kvasiautomatiske prosedyrer, bygger den norske ordningen altså på vurderinger av bevis og skjønnsbaserte vedtak, og kan kun anvendes dersom det er utlendinger som er forskjellsbehandlet. Ansvaret for kontroll og håndheving tilligger Arbeidstilsynet og Petroleumstilsynet, som nylig har fått styrkete sanksjonsmuligheter overfor brudd på forskriftsbestemmelser om allmenngjøring. Praktiseringen av loven har vært kritisert, bl.a. for å være i strid med EU-rettens krav til likebehandling, forutsigbarhet og propor- 
sjonalitet (Hjelmeng og Kolstad 2006) ${ }^{18}$, og er nå under evaluering. Som følge av den økende tjenestemobiliteten har det i tillegg til debatten om allmenngjøringsinstituttet også vært luftet ideer om innføring av nasjonal minstelønn hjemlet i lov og/eller bransjevise avtaler.

(28) Ved siden av svært ulike reguleringsformer, er det nordiske forskjeller i synet på hvilket relative lønnsnivå praktiseringen av likebehandlings/vertslandsprinsippet for utstasjonerte arbeidstakere skal referere til. På Island viser lovgivningen som omfatter utstasjonerte arbeidstakere til minstesatsene i tariffavtalene. I Norge har fagforeningene nøyd seg med å stille krav om allmenngjøring av visse minstesatser i avtalene, samt arbeidstid, enkelte obligatoriske tillegg og sosiale bestemmelser, slik at det allmenngjorte lønnsnivået ligger godt under det gjennomsnittlige faktiske lønnsnivået for sammenliknbart arbeid i bransjen. Dette gjenspeiler at fagforeningene ønsker å opprettholde visse fordeler ved å være medlem i fagforening med tariffavtale, sammenliknet med uorganiserte nasjonale arbeidstakere som ellers kunne høste gratisgevinster gjennom allmenngjøring av avtalene. Dette står i en viss kontrast til Finland hvor minstelønnssatsene, samt alle de individuelle bestemmelsene i tariffavtalen allmenngjøres. Den reviderte loven om utstasjonering krever «sedvanlig och skälig» lønn for de som ikke omfattes av allmenngjøring, mens arbeidsavtaleloven sikrer innleide arbeidstakere lønn i tråd med anvenderforetakets avtale eller, i andre hånd, i tråd med generelt gyldig avtale innen avvenderforetakets bransjeområde. I Danmark og Sverige, hvor lønnsdannelsen i større grad er lokal, har fagforeningene avvist minimallønnssatsene i de nasjonale avtalene som utgangspunkt for forhandlinger med utenlandske selskap og stiller vanligvis krav som i sterkere grad er relatert til - men ikke nødvendigvis identisk med - det faktiske lønnsnivået for sammenliknbart arbeid i bransjen/regionen. De ulike nordiske fagforeningsstrategiene illustrerer noe ulike avveininger mellom hensynet til å forebygge konkurransevridning og hensynet til å opprettholde avtalefordeler for medlemmene. Dette har også å gjøre med at de øvrige incentivene til fagorganisering er sterkere i de landene hvor ledighetskassene i stor grad er knyttet til fagforeningene (Danmark, Finland, Island og Sverige). De ulike nasjonale tradisjonene når det gjelder lønnsdifferensiering mellom avtalebundne og ikke avtalebundne bedrifter gjenspeiles også i arbeidsgiversidens syn på hvordan vertslandsprinsippet skal praktiseres. At arbeidsgiversiden har vært vant til allmenngjøring av alle de individuelle bestemmelsene i tariffavtalen i Finland - og i Sverige og Danmark tradisjonen med henge/tiltredelsesavtaler - har sikret et relativt enhetlig lønnsnivå og like konkurransevilkår mellom nasjonale firma og EØSleverandører. I Norge har de sentrale arbeidsgiverorganisasjonene (som tilbyr medlemskap uten avtaleforpliktelser) tradisjonelt vært mindre opp-

\footnotetext{
${ }^{18}$ Erling Hjelmeng og Olav Kolstad (2005), Allmenngjøringsloven og innsynsrett -EØS-rettslige problemstillinger http://odin.dep.no/filarkiv/269459/NHO___vedlegg.pdf
} 
tatt av denne typen konkurransevridning og bedriftene har vært vant til å kunne hyre inn billigere underleverandører av både nasjonal, nordisk og europeisk opprinnelse. Selv om også svenske arbeidsgivere, for eksempel i Laval/Vaxholmsaken, har sådd tvil om fagforeningenes fortolkning av vertslandsprinsippet og konfliktretten, har fagforeningenes krav om avtalebasert lønn for utstasjonerte arbeidstakere (og allmenngjøring) vært langt mer omstridt i Norge og bidratt til betydelig splid på den norske arbeidsgiversiden. Heller ikke fagforeningene har hittil ønsket å ta i bruk allmenngjøring i industrien, hvor lokale tillitsvalgte i mange bedrifter har måttet akseptere hyring av underentreprenører fra EU-8 med lønninger betydelig under minstetariff. På samme måte som det er betydelige forskjeller i lønnsnivå mellom de nordiske landene - for eksempel er det hevdet at de allmenngjorte minstesatsene i den norske byggfagsoverenskomsten er omtrent på nominelt nivå med gjennomsnittslønnen for tilsvarende arbeid i Sverige - har de nordiske landene med andre ord forskjellige virkemidler, tradisjoner og kultur når det gjelder hvilke lønnsforskjeller som aksepteres mellom bedrifter med og uten avtale, og mellom innenlandske og utenlandsk virksomheter.

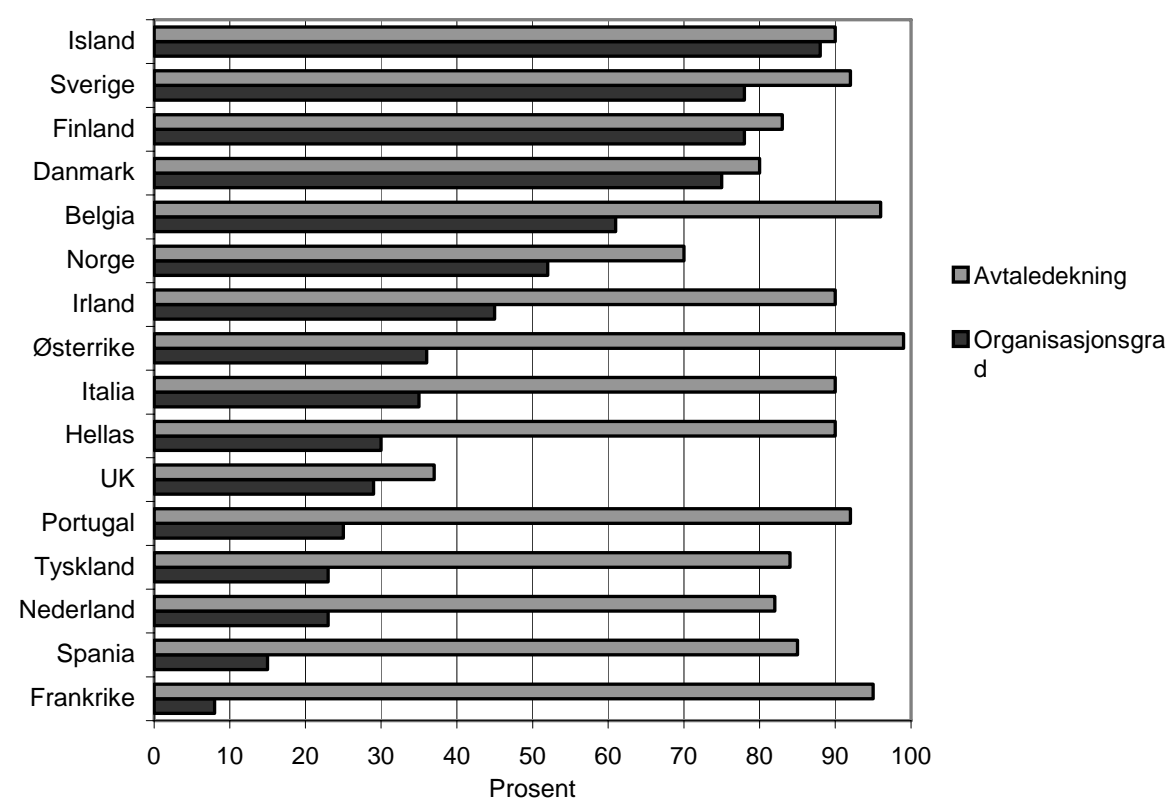

Figur 4 Faglig organisasjonsgrad og kollektivavtaledekning i EU-15, Island og Norge. Kilde: Stokke 2005 og ASI 2006. 
Employers organisational rates in selected EU/EEA countries Source: Stokke 2005, based on Traxler et al 2001

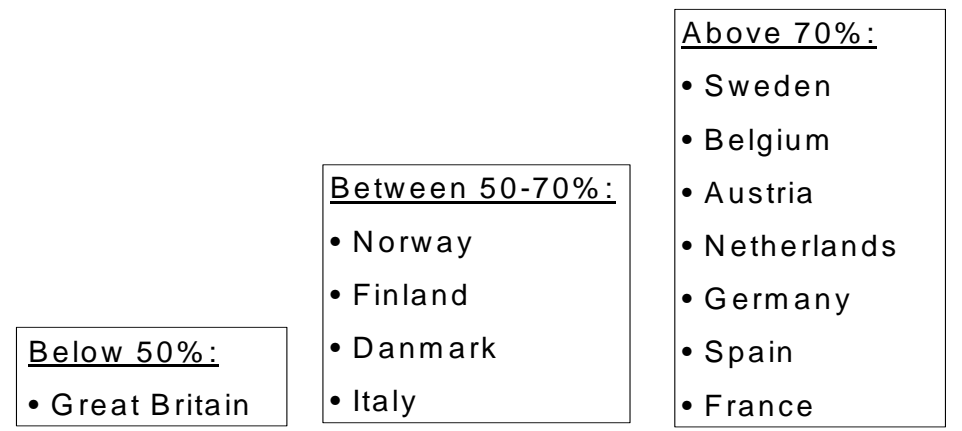

Figur 5 Organisasjonsgrad på arbeidsgiversiden

\subsection{Håndheving, kontroll og sanksjoner}

(29) En av de viktigste arbeidsmarkedspolitiske virkningene av EUutvidelsen er at den ytre (grense)kontrollen med vilkårene for adgang til det nasjonale arbeidsmarkedet fra de nye EU-landene bygges ned. Med økende arbeids- og tjenestemobilitet betyr det at kravene til intern kontroll med spillereglene i arbeidslivet skjerpes, samtidig som EU-rettslige føringer får økt betydning. I alle de nordiske land er det gjennomført et spekter av tiltak for å styrke de indre kontroll- og håndhevingsregimene, men fra alle landene meldes om vansker med å oppdage, motvirke og sanksjonere omgåelser. Både for de nasjonale oppdragsgiverne, de utenlandske oppdragstakerne - og delvis også arbeidstakerne - er det betydelige økonomiske gevinster å hente på underleveranser bygd på omgåelse av bestemmelser knyttet til lønn eller skatter/avgifter, arbeidsmiljø/HMS, boforhold el. «Svarteper» i slike trekantspill vil alltid være fellesskapet og de seriøse bedriftene, men altfor ofte blir også den svakeste part i spillet de utenlandske arbeidstakerne - utsatt for sosial, økonomisk og helsemessig risiko. I et høymobilt, grenseoverskridende marked med juridiske gråsoner mellom ulike arbeidstakerforhold, uoversiktlige rettsregler, lange og komplekse underleverandørkjeder og høy omskiftelighet, er kontroll- og håndhevingsoppgavene meget krevende. Oppgavene involverer en rekke myndighetsinstanser, parter, bedrifter og brukere. Uansett reguleringsform stiller dette store krav til samarbeid, koordinering og informasjonsdeling mellom ulike myndighetsinstanser og andre samfunnsaktører, både i mottaker- og senderlandene. Ved siden av å videreutvikle/tilpasse de nasjonale reguleringsregimene til en situasjon med høyere 
mobilitet og langt sterkere incentiver til omgåelser/unndragelser enn man har vært vant til i nordisk sammenheng, vil evnen til å takle håndhevingsutfordringene etter vår vurdering være kritisk for å sikre <ordning och reda> i det felles arbeids-og tjenestemarkedet. Håndheving av spillereglene er ikke bare avgjørende for å hindre ågerkarer og kortsiktige lykkejegere fra å berike seg på andres bekostning, men for å hindre at nasjonale standarder, arbeidslivsregimer og det indre markedets potensial for velstandsutvikling undermineres av regimeshopping og sosial dumping.

(30) I de følgende avsnittene vil vi derfor gi et riss av de temaene og problemstillingene vi oppfatter som mest sentrale på agendaen, for å utvikle registrering, kontroll- og håndhevingsregimer som er bærekraftige i et åpent arbeids- og tjenestemarked.

I utgangspunktet er det viktig å være klar over at de nordiske landene som følge av variasjonene i nasjonal lønnsregulering har meget ulike vilkår og virkemidler for kontroll og håndheving av lønns- og arbeidsvilkår for utstasjonerte arbeidstakere (og direkteansatte fra EU-8 når overgangsregimene er faset ut). I Finland, Island og delvis Norge, hvor utstasjonertes rettigheter er hjemlet i lov og/eller forskrift om allmenngjøring, hviler hovedansvaret for kontroll og håndheving på Arbeidstilsynet, som i alle landene melder om betydelige problemer i de flyktige tjenestemarkedene. ${ }^{19}$ I Sverige og Danmark hviler hovedansvaret for tilsyn med lønnsvilkår på fagforeningene, med hjelp fra arbeidsgiverne, som har gitt fagforeningene arbeidskrevende oppgaver og en vanskelig dobbeltrolle $\mathrm{i}$ gjennomføringen av EUs utstasjoneringsdirektiv. Fagforeningene skal dels sikre ordentlige lønns-og ansettelsesvilkår (‘ønnspoliti>-rollen) gjennom inngåelse av henge/tiltredelsesavtaler og ivareta kontrolloppgaver i forhold til utstasjoneringens lovlighet og overholdelse av arbeidsmiljølovgivningen mv ('grensevakt)-rollen), og dels beskytte/støtte utenlandske arbeidstakere mot utnyttelse og eventuelt utvisning/tap av arbeid («solidaritets >-rollen). Dette har innebåret betydelige forklarings- og legitimitetsutfordringer overfor utenlandske bedrifter, arbeidstakere og myndigheter, samt den hjemlige offentligheten, som ikke uten videre forstår at fagforeningene faktisk utøver (europeiske implementerings)roller som de facto er betrodd dem av landets politikere under til dels sterk profilering på EU-nivå.

\section{Registering - en nødvendig men omstridt forutsetning for kontroll}

(31) En viktig forutsetning for å utøve kontroll med lønns-og arbeidsvilkår hos utenlandske firma og arbeidstakere er at man har tilstrekkelig statistikk og informasjon om hvilke aktører som opererer i det innenlandske markedet. Spesielt gjelder dette i tjenestemarkeder med kortvari-

\footnotetext{
${ }^{19}$ Også i disse landene har fagforeningene med sin tilstedeværelse og aksjonsmuligheter en viktig rolle i kontrollen og håndhevingen. I Norge har fagforeningene fått adgang til 'håndhevingsboikott' overfor bedrifter omfattet av allmenngjøring, og har reist krav om lovfestet rett til innsyn i lønnsvilkårene hos underleverandører.
} 
ge, flyktige oppdragsrelasjoner, hvor aktørene vanskelig vil oppdages gjennom rutinemessige/sporadiske kontroller over tid. Tilgang til slik informasjon forutsetter i praksis en eller annen form for registrering, noe som praktiseres i flere europeiske land, deriblant Belgia, Frankrike og Tyskland. Utstasjoneringsdirektivet regulerer ikke mulighetene for å iverksette konkrete kontrolltiltak, herunder registrering. Rammene for hvilke kontrolltiltak som kan iverksettes overfor en tjenesteyter følger av EU-traktatens grunnprinsipp om fri bevegelse av tjenester, som kun kan begrenses ut fra tvingende allmenne hensyn, hvoriblant hensynet til beskyttelse av arbeidstakerne og hensynet til å unngå forstyrrelser i arbeidsmarkedet er blant dem EF-domstolen har anerkjent i sin rettspraksis. I den grad registrering kan være en særskilt ulempe/byrde for utenlandske leverandører av kortvarige tjenester, vil enhver registreringsordning måtte være i samsvar med EF-domstolens kriterier for hva som ut fra allmenne hensyn er legitime inngrep i den frie bevegelsen, nemlig at tiltaket innfrir kravene til likebehandling, egnethet til å oppnå formålet, og proporsjonalitet. ${ }^{20}$ Hensynet til formål og proporsjonalitet refererer til en annen viktig forutsetning for registreringstiltak, nemlig at vertslandet har klare og allmenne regler som kontrollformålet for registreringen kan prøves mot på en likeartet måte for innenlandske og utenlandske aktører.

(32) Med andre ord: vilkåret for å opprette registreringsordninger for å kontrollere lønns-og arbeidsvilkår hos utenlandske tjenesteytere og utstasjonert arbeidskraft er at vertslandets lovregler og praksis stiller krav om bestemte lønns- og arbeidsvilkår og hjemler slik kontroll blant innenlandske arbeidstakere. Man kan altså ikke opprette en registreringsordning for å kontrollere lønnsvilkårene hos utstasjonerte arbeidstakere dersom vertslandet - som i Sverige og Danmark - ikke har lovhjemlete regler for lønn blant tilsvarende innenlandske arbeidstakere. Allmenngjorte tariffavtaler i Finland, Island og Norge er derimot eksempler på lovregulering som hjemler offentlig tilsyn og dermed kan begrunne en registreringsordning. I kontrast til Sverige og Danmark, har følgelig Finland og Island i 2006 innført plikt til registrering av utenlandske underleverandører og deres arbeidstakere. Norge har med henvisning til skattemessige formål lenge hatt regler for registrering/innrapportering av utenlandske firma og ansatte i offshore- og bygg-og anleggssektoren og vedtok i 2004 å innføre en generell slik rapporteringsplikt i alle bransjer. Denne er hittil bare innført for arbeidstakere knyttet til entrepriseoppdrag, men ikke for andre arbeidstakerforhold på grunn av tvil om samsvaret med EU-retten (St.meld. nr. 9 2005-2006). Danmark har i 2006 vedtatt en liknende registrering/rapporteringsordning i bygge- og anleggssektoren, hvor motivet er å finne ut når ut det oppstår skatteplikt til Danmark. Som tidligere nevnt har Finland og Island, i likhet med England og Irland også innført registreringsplikt for alle direkteansatte/individuelle ar-

\footnotetext{
${ }^{20}$ Se for eksempel Bruun mfl 2005, Kolstad og Hjelmeng 2006, Evju 2006, Maier 2005, Beskæftigelsesministeriet 2006.
} 
beidsmigranter, men slike ordninger vil etter alt å dømme kun være legititimt innen overgangsperioden fram til 2009 da reglene for fri bevegelse av arbeidskraft inntrer. Også Norge vedtok i 2004 å innføre meldeplikt for alle EU-og EØS-borgere som skal drive erhverv, tjenester eller arbeid i landet i mindre enn tre måneder, og derfor ikke trenger oppholdstillatelse, men myndighetene har foreløpig ikke satt ordningen i kraft.

(33) I et notat fra det danske Beskæftigelsesministeriet (24.02.06) som vurderer mulighetene for å opprette registreringsordninger for utstasjonerte innenfor EU-rettens rammer, drøftes alternative (indirekte) grunnlag for registrering, deriblant arbeidsmiljølovgivningen, som utenlandske firma er forpliktet til å følge. Notatet konkluderer imidlertid med at Arbeidstilsynet kun har behov for å vite hvilken bransje virksomheten tilhører, og om den har ansatte, mens nærmere opplysninger om antallet og personlige opplysninger om de ansatte ikke er relevante for å sikre overholdelsen av den danske arbeidsmiljøloven. Tilsvarende drøfter notatet også andre mulige formål og lovgrunnlag, såsom et ønske om å sikre arbeidsmarkedets parter informasjon med sikte på å inngå overenskomst, samt kontroll med individuelle arbeidsvilkår nedfelt i utstasjoneringsloven (blant annet likebehandling), men konklusjonen synes å være at registrering ut fra slike formål ikke vil innfri kravet til likebehandling og proporsjonalitet, all den tid slik myndighetskontroll ikke utøves i forhold til innenlandske danske arbeidstakere.

Ut fra dagens EU-regler kan det altså se ut som om man bare vil kunne opprette registreringsordninger for å kontrollere lønnsforhold blant utstasjonerte og utenlandske arbeidstakere dersom vertslandet har lovfestede eller allmenngjorte bestemmelser om lønn. Landene er dermed henvist til registrering på annet grunnlag, først og fremst med sikte på å kontrollere inntreden av skatteplikt blant utenlandske tjenesteytere og utstasjonerte arbeidstakere - slik det er vedtatt i Norge og Danmark - samt moms- og ervervsregistrering. Mens sistnevnte ikke legitimerer innsamling av annet enn basisopplysninger om firmaet og omsetning, tyder de norske erfaringene på at det skal sterke incentiver og sanksjoner til for å motivere nasjonale oppdragsgivere til systematisk innberetning av alle utenlandske ansatte hos underleverandører. Det norske SFU har meldt om betydelig underrapportering, blant annet fordi slik rapportering er innholds- og arbeidsmessig krevende, og fordi risikoen (sanksjonene) ved å la være har vært lav. Det siste året har imidlertid antallet innrapporterte blitt tredoblet, hvilket trolig både reflekterer økt mobilitet,bedre registreringsdisiplin og at flere er omfattet av registreringsplikten.

(34) Danmark har også besluttet å innføre en systematisk registrering av utstasjonerte som i hjemlandet har fått utstedt blankett E-101 (bekrefter trygderettigheter og ansettelsesforhold i opprinnelseslandet) med hjemmel i forordning 1408/71. Senderlandene er forpliktet til å føre dataregistre over personer som har mottatt E-101 blanketter, men mye tyder 
på at oversikten er svært mangelfull. ${ }^{21}$ Tilgang til slik informasjon kan blant annet være nyttig for å kontrollere om ansettelsesforholdet og utstasjoneringen er reell, om vilkårene for lovlig utstasjonering er tilstede eller om man har å gjøre med fordekt utleie eller ansettelse i vertslandsbedrift, hvilket igjen har konsekvenser for skattemessige forhold både i hjem- og vertsland.

I likhet med de fornnevnte ordningene for moms- og skatteregistrering, synes det for oss å være behov for utveksling av mer konkret informasjon og erfaringer mellom landene om hvilken nytte og hvilke beskrankninger (bl.a. når det gjelder etat-utveksling og kopling av data) bruk av slike registre innsamlet med skatte-og trygdemessige formål har når det gjelder å kontroll og håndheving av arbeids- og lønnsvilkår blant utstasjonerte arbeidstakere. Ikke minst gjelder dette utviklingen av samarbeid med senderlandenes myndigheter på feltet, som er en forutsetning for effektiv kontroll.

(35) I Kommisjonens opprinnelige utkast til tjenestedirektiv ble det (i artikkel 24 og 25) foreslått å forby visse typer kontrollmotiverte tiltak og krav fra vertslandets side. Dette gjaldt blant annet

- krav om å ha en representant tilstede i vertslandet;

- krav om autorisering, registrering eller liknende forpliktelser hos vertslandets myndigheter;

- krav om ha bestemte originale sosiale dokumenter på arbeidsplassen;

I det omarbeidete kompromissforslaget fra Parlamentet og Rådet ble disse artiklene strøket. På denne bakgrunnen har Kommisjonen utarbeidet en Kommunikasjon med retningslinjer for utstasjonering av arbeidstakere (COM (2006) 159final), hvor den dels forsøker å klargjøre hva den mener er aquis (gjeldende EU-rett) når det gjelder hva som er proporsjonale tiltak for å sikre kontroll, dels trekker opp rammene for en prosess med sikte på klargjøring av rettstilstanden og forbedring av medlemslandenes kontroll og håndheving av utstasjonertes rettigheter. Selv om Kommisjonens utlegning av rettsläget i retningslinjene er omstridt (se feks Bruun 2006), synes budskapet å være at:

- krav om fast representasjon er tvilsomt (men en utpekt ombudsmann blant de ansatte er greit);

- krav om forhåndsautorisasjon og forhåndsregistrering/kontroll er uproporsjonalt (med unntak for spesielle yrker, vikarbyråer mv som er underlagt autorisasjonskrav i vertslandet);

- krav om forhåndsdeklarasjon med nødvendig informasjon for at vertslandets myndigheter skal kunne utøve sin plikt til

\footnotetext{
${ }^{21}$ For eksempel har vi fått opplyst av det i henhold til det polske E-101-registret ikke er flere enn noen hundre utstasjonerte polakker i Norge, mens alt tyder på at reelle tallet er mange tusen.
} 
effektiv/målrettet kontroll og håndheving på arbeidsplassene synes akseptabelt;

- krav om originale ansettelsesdokumenter er urimelig, men bemannings-, HMS,- og timelister som er nødvendig for kontroll er greit.

(36) Kommisjonens forsøk på å oppsummere EF-domstolens rettspraksis på feltet er naturlig nok gjenstand for tolkningsstrid og markerer snarere starten enn slutten på en prosess for å klargjøre de politiske og rettslige rammene for utøvelsen av kontroll og håndheving på feltet. For Danmark og Sverige er for eksempel muligheten til å kreve en representant i vertslandet avgjørende for mulighetene til å inngå tariffavtaler, og en sak siste ordet neppe er sagt om. Danmarks og Norges krav om registrering hos skattemyndighetene er neppe omstridt, men Finlands nye regler om registrering, plikt til å oppnevne en uavhengig ombudsmann, lønnsinformasjon mv, går nok noe lenger enn Kommisjonens restriktive tolkning av rettspraksis. Formålet her er imidlertid ikke å forsøke å trekke opp grensene for hva som er forenlig med EU-retten (kfr notat fra NMR-utvalg for arbeidsrett), men for det første å peke på noen av de sentrale hensyn og problemstillinger som definerer handlingsrommet i forhold til EU-retten på området; for det andre, å peke på at politikken og jussen på området er i støpeskjeen og at dette vil være et viktig felt for de nordiske land å gjøre sine syn og interesser gjeldende på europeisk plan. Et hovedbudskap i Kommisjonens dokument er således understrekningen av medlemslandenes plikt til å ta alle nødvendige tiltak for sikre effektiv håndheving av utstasjonertes rettigheter, inklusive virksomme sanksjoner; behovet for opprusting av informasjon, liason-kontorer og ordninger hvor utstasjonerte kan få løst sine problemer og tvister; økt administrativt samarbeid mellom landene, samt varsling om en grundig evaluering og dialog med medlemslandene om vilkårene for en mer effektiv implementering, og om nødvendig revisjon, av utstasjoneringsdirektivet. Kommisjonen har også varslet at den vil vurdere reaksjoner mot land med mangelfull implementering av direktivet. Med andre ord: Det kommende året vil være en politisk besøkelsestid for både å få skikk på det hjemlige kontroll-og håndhevingsregimet og drive aktiv påvirkning av premissene for evalueringen og den politiske behandlingen av spørsmålet på EU-nivå.

\section{Innsyn i lønns-og arbeidsvilkårhos underentreprenører og utleiefirma}

(37) Uansett reguleringsregime spiller fagforeningene en viktig rolle i det løpende tilsynet med at ting går ordentlig for seg på arbeidsplasser med utenlandske underentreprenører. Muligheten til faglig innsyn i lønns-og arbeidsvilkår hos underentreprenører har således stått sentralt i alle de nordiske land. I en rekke europeiske land er det vanlige at fagforeningene gjennom avtaler med sin arbeidsgiver har en indirekte innsynsrett i for- 
hold til underentreprenører, mens en generell, direkte faglig innsynsrett er uvanlig (Stokke 2006). EU-retten setter også grenser for mulighetene til å gi utenforstående aktører (3.part) rett til innsyn i bedriftenes forretningsmessige og konkurransesensitive forhold eller kontrakter (Hjelmeng og Kolstad 2006). Den svenske MBL har lenge hjemlet informasjons- og drøftingsrettigheter om vilkårene for hyring av underentreprenører for tillitsvalgte i oppdragsbedriften, og rammeavtalen mellom de sentrale partene i Sverige i 2005 knesatte at fagforeningene hos oppdragsbedriften og deres fagforbund skal ha rett til innsyn i og kontroll av lønns-og arbeidsvilkårene hos underentreprenører. Slik informasjonstilgang er også sedvanlig avtalebasert praksis i Danmark. I Finland styrket den reviderte utstasjoneringsloven av 2006 retten til innsyn for fagforeninger/forbund med avtale med oppdragsbedriften, samtidig som den nye ombudsmannen for utenlandske underentreprenører skal kunne legge fram relevant informasjon om vilkårene for de utstasjonerte arbeidstakerne - hvilket kan indikere en noe bredere og mer generell innsynsrett. På Island har fagforeninger og forbund med hjemmel i lovgivningen om avtalebasert minstelønn fått rett til å få se lønnsinformasjon fra utenlandske firma med utstasjonerte arbeidstakere, trolig den mest vidtgående generelle innsynsretten i Norden. Norge har inntil 2006 ikke hatt rettigheter knyttet til innsyn i lønnsforhold hos underleverandører - selv om arbeidsmiljøloven og en del tariffavtaler har gitt fagforeningene rett til drøfting, og i noen tilfelle forhandlinger, om saker vedrørende hyring av leiefirma - så saken ble et sentralt stridstema ved tariffoppgjøret i 2006. Arbeidsgiverne har med støtte i juridiske betenkninger (Hjelmeng og Kolstad 2006) avvist innsyn for fagforeninger med henvisning til styringsretten, konkurranse-, forretnings- og personvernhensyn, men gikk i tariffoppgjøret i bl.a. industrien og byggfagene med på en betinget plikt til å legge fram dokumentasjon av lønns- og arbeidsvilkår for tillitsvalgte i oppdragsbedriften, under forutsetninger om vern av person- og konkurransesensitiv informasjon, samt taushetsplikt overfor offentligheten, med unntak for relevante offentlige tilsynsmyndigheter. Fagforeningene fikk også avtalefestet retten til drøfting av behov og omfang ved innleie og bortsetting av arbeid. Norsk LO har tatt til orde for en mer generell lovhjemlet innsynsrett. Regjeringen har med henvisning til juridiske skranker ikke sett ut til å ville imøtekomme dette kravet, men har signalisert at den vurderer å foreslå en lovfestet innsynsrett i virksomheter som er omfattet av allmenngjøringsforskrifter. Det gjenstår å se hvilke aktører denne innsynsretten eventuelt skal omfatte. Tariffavtalepartene har i henhold til allmenngjøringsloven i Norge rett til å boikotte bedrifter som mistenkes for å bryte bestemmelsene, men etter fagforeningenes syn er en slik rett av begrenset verdi så lenge de ikke kan få informasjon om de faktiske lønnsforholdene i den aktuelle bedriften.

(38) Spørsmålet om innsynsrett, og betingelsene og avgrensningene av en slik rett, illustrerer på samme måte som registreringsspørsmålet, hvor- 
dan det juridiske og politiske handlingsrommet på feltet defineres i skjæringsfeltet mellom nasjonale reguleringsformer (lov/allmenngjøring vs avtale), regler og praksis overfor innenlandske bedrifter, og EU-rettens krav om likebehandling og proporsjonalitet. Indirekte innsynsrett for tillitsvalgte i oppdragsgiverbedriften synes uproblematisk, forutsatt adekvat lov- eller avtaleforankring, mens innføring av innsynsrett for aktører utenfor den direkte kontrakts/avtalerelasjonen mellom oppdragsbedriften og dens ansatte reiser en rekke uoversiktlige problemstillinger både $\mathrm{i}$ forhold til personvern, nasjonal forretnings- og konkurranserett og reglene for fri bevegelse i EU.

\section{(39) Byggherre/oppdragsgiver/bestilleransvar.}

Et viktig, men komplisert tema, er hvilket ansvar kjøpere av tjenester skal ha når det gjelder leverandørers og underentreprenørers ivaretakelse av egne ansattes arbeids- og lønnsvilkår. Innenfor byggebransjen har dette lenge vært et problematisk felt, uavhengig av om underentreprenørene og ansatte er utenlandske. Kontrakts- og produksjonskjedene er gjerne lange, og det er ikke nødvendigvis gitt hvor i kjeden ansvaret for at kravene oppfylles skal plasseres. Erfaringene har vist at økt forekomst av utenlandske underleverandører forsterker problemene, og EU-utvidelsen har derfor aktualisert behovet for forbedringer i eksisterende lov- og regelverk. ${ }^{22}$ Konkrete eksempler på dette er nye lovforslag i Finland og Norge. I Finland foreligger det nå et lovforslag «om beställarens redogörelseskyldighet och ansvar vid anlitande av utomstående arbetskraft». Formålet med loven er å skape like konkurransevilkår mellom bedriftene, overvåke arbeidsvilkår, samt å sikre grunnlaget for at underentreprenører og kjøper av tjenestene oppfyller sine forpliktelser. Det skal tillegges bestilleren av underleveranser og tjenester å utrede om leverandøren er behørig registrert og har betalt lovfestede avgifter. Videre skal det redegjøres for pensjonsforsikringer/avgifter, kollektivavtale og sentrale arbeidsvilkår. Opplysningsplikten skal være like omfattende for utenlandske virksomheter som for finske. Omgåelse av «redogörelsesskyldigheten» kan i følge forslaget føre til ileggelse av forsømmelsesavgift. Det foreslås også å innføre en bestemmelse om at bestilleren på forespørsel skal informere om gjeldende avtale for «utomstående» arbeidskraft. I de andre nordiske landene diskuteres også ulike forslag om utvide byggherre/oppdragsgivers ansvar i forhold til entreprenørkjeden. På europeisk plan har partene i byggebransjen stilt krav om «liability». Kommisjonen har uttrykt positive holdninger til dette på prinsipielt nivå, men ikke fremmet saken på europeisk plan. I Norge har de foreløpige erfaringene med allmenngjorte tariffavtaler brakt opp spørsmålet om hvem som skal ha ansvaret for at forskriftene følges. I forbindelse med et forslag til end-

\footnotetext{
${ }^{22}$ Se for eksempel rapporten fra det norske samarbeidsprosjektet «Seriøsitet i byggenæringen» http://www.fellesforbundet.no/upload/NYHETER/Svartvedlegg.pdf
} 
ringer i reglene om Arbeidstilsynets kompetanse til å føre tilsyn etter allmenngjøringsloven og utlendingsloven ${ }^{23}$, ble det også lagt fram forslag om at byggherrer (i byggebransjen) skal være forpliktet til å ta inn en klausul i sine kontrakter med oppdragstakere, hvor de informerer om at arbeidstakerne skal ha lønns- og arbeidsvilkår i tråd med gjeldende forskrifter om allmenngjøring av tariffavtaler. Byggherrer er allerede pålagt et ansvar for helse, miljø og sikkerhet, og dette innebærer en utvidelse av byggherreansvaret. Det presiseres imidlertid i lovens forarbeider at bestemmelsen skal ivareta informasjonshensyn, og at oppdragsgivere ikke vil få ansvar for manglende overholdelse av kontraktsklausulene. Et særskilt tema i alle landene er om og eventuelt hvilke (sosiale) krav det offentlige skal stille ved bestilling av oppdrag (jfr ILO-konvensjon nr. 94 og upphandlings/innkjøpsdirektivet 2004/18/EEC). ${ }^{24}$

\section{(40) Bemanningsbyråer og utleie/innleie av arbeidskraft.}

Bruken av vikarer og innleid arbeidskraft er økende i hele Europa, og utgjør mellom 1 til 2 prosent av sysselsettingen. ${ }^{25}$ Vilkårene for å drive utleiebyrå er de seinere årene betydelig liberalisert i de nordiske landene og det er i dag et bredt tilbud av nasjonale og utenlandske personalbyråer som leier ut østeuropeisk arbeidskraft til nordiske firma. I tillegg kan nordiske foretak leie inn arbeidskraft fra utenlandske datterselskap eller samarbeidspartnere. Inn- og utleie av arbeidskraft er regnet som tjenesteyting etter EØS-regelverket, og i utgangspunktet vil arbeidstakere som leies ut fra bemanningsbyråer i hjemlandet ikke komme inn under eventuelle overgangsordninger. I Norden er dette nå bare en aktuell problemstilling i Danmark og Norge, som har en ulik fortolkning av regelverket. I Danmark omfattes også innleide fra EU-8 som er ansatt i byråer i hjemlandet av overgangsordningen, mens dette i Norge kun gjelder arbeidstakere som er ansatt i og leies ut fra byråer basert i Norge. Dersom de leies ut fra virksomheter basert i utlandet, regnes de som utstasjonerte arbeidstakere som ikke omfattes av overgangsordningen, og dermed heller ikke av kravet om «norsk lønn». Hvis arbeidet utføres innenfor et område med allmenngjort tariffavtale, gjelder imidlertid denne også for innleid arbeidskraft. De to landenes ulike tolkninger på dette feltet illustrerer vanskene knyttet til grensedragningen mellom bevegelse av tjenester og arbeidskraft. I Danmark og Sverige reguleres innleide vikarers lønn gjennom tariffavtaler, i Norge delvis gjennom tariffavtaler eller allmenngjorte tariffavtaler, men er for innleide vikarer fra EU-8 i stor grad uregulert . I Finland er det lovfestet (gjennom arbeidsavtaleloven), at dersom beman-

\footnotetext{
${ }^{23}$ Ot.prp.nr. 92 (2005-2006)

${ }^{24}$ Se SOU 2006:28 for en grundig gjennomgang av status i Sverige (og Norden): http://www.regeringen.se/content/1/c6/06/03/33/447d389e.pdf

${ }^{25}$ European Foundation for the Improvement of Living and Working Conditions (2006), Temporary agency work in an enlarged European Union. Dublin. http://www.eurofound.eu.int/pubdocs/2005/139/en/1/ef05139en.pdf
} 
ningsforetaket ikke er bundet av kollektivavtale eller allmenngjort tariffavtale, skal vikaren lønnes med utgangspunkt i oppdragsbedriftens kollektivavtale. ${ }^{26}$ På Island ble det i 2005 innført en ny lov for bemanningsselskap/vikarbyråer, basert på en gjensidig avtale mellom myndighetene og partene. Loven pålegger vikarbyråer som leverer tjenester til virksomheter på Island å melde fra åtte dager før arbeidet starter opp. Det skal blant annet informeres om byråets adresse og kontaktperson, både på Island og i hjemlandet, og firmaet blir så registrert i Arbeidsdirektoratet. Uregistrerte firmaer har ikke lov til å levere tjenester. Hvis tjenestene leveres for en periode på over 10 dager skal navn, adresse og kvalifikasjoner på de enkelte arbeidstakerne oppgis. De ansatte skal ha arbeids- og lønnsvilkår i tråd med islandske avtaler og arbeidslovgivning. I Norge opphevet man i 2003 registreringsplikten for utleiebedrifter, men arbeidsmarkedsloven gir fortsatt hjemmel og mulighet til å fastsette forskrifter om vilkår for rapportering, tilsyn m.m. av utleievirksomhet. I Sverige inngikk partene i 2004 en avtale om frivillig autorisering av bemanningsselskaper. For å bli autorisert må selskapet være medlem i arbeidsgiverorganisasjonen (Bemanningsföretagen/Svenskt Näringsliv), følge deres etiske retningslinjer og akseptere de kollektive avtalene. I løpet av det første året etter avtalens inngåelse ble 79 selskaper autorisert. I lys av fremveksten av et grenseoverskridende korttidsarbeidsmarked, i stor grad organisert gjennom internett, synes det å være behov for kunnskaps- og erfaringsutvikling om aktuelle tiltak både på nordisk og europeisk plan. Direktivforslaget om vikarbyråer er blokkert i Rådet, og det er uklart om saken vil komme opp igjen under det finske formannskapet. EURES representerer videre en alternativ kanal for formidling, som aktualiserer spørsmålet om de nordiske lands myndigheter i kombinasjon med bedre informasjon og kontroll kan bidra til å utvikle bedre og tryggere rammer for korttidsarbeidsmarkedet rundt Østersjøen.

\footnotetext{
${ }^{26}$ For detaljer om de nasjonale reguleringene, se: http://www.eiro.eurofound.eu.int/thematicfeature14.html
} 



\section{Avslutning}

(41) I tilbakeblikk synes det nå klart at tilstrømmingen av arbeidskraft fra de nye EU-landene til Norden har blitt høyere enn ventet, men også er langt skjevere fordelt enn ventet. I en av de mest kjente framskrivningene gjort av Boeri og Brücker (2003) anslo man at nettoinnvandringen fra EU-8 til Norden ville øke fra rundt 50,000 til 230,000 innen 30 år, dvs i gjennomsnitt rundt $6000 \mathrm{i}$ året og sannsynligvis noe flere de første årene. Omlag 40 prosent ble antatt å være yrkesaktive. Etter to år kan vi oppsummere at det i Norden er utstedt om lag 75,000 førstegangstillatelser til opphold for borgere fra EU-8 i forbindelse med arbeid og nesten 30,000 fornyelser. Selv om en betydelig andel av tillatelsene gjelder midlertidig arbeid - såkalt svingdørsmigrasjon - viser utviklingen i gyldige/aktive tillatelser at antallet individuelle arbeidsmigranter bare i Norge vil variere mellom 13,000 og 40,000 i 2006, tilsvarende 0,6-1,8 prosent av sysselsettingen. Mens det per 1.juli 2004 var registrert rundt 11976 gyldige tillatelser, var antallet samme tid i 2006 økt til 28596 , dvs mer enn fordobling på to år. Antallet utstedte oppholdstillatelser til arbeid i 2005 utgjorde ca 1,6 prosent av arbeidsstyrken og vil i 2006 trolig passere 2 prosent, hvorav omtrent halvparten begge år er fornyelser. I Norge kan en også spore en økning i antallet arbeidsmigranter som bosetter seg og henter med familien, selv om tallene foreløpig er moderate: nettoinnflyttingen fra EU-8 til Norge utgjorde4213 personer i 2005, ${ }^{27}$ tilsvarende 22 prosent av samlet nettoinnflytting. På Island har den relative veksten i arbeidsimmigrasjon vært enda sterkere, og antallet utstedte tillatelser bare i perioden 1.januar-30.april 2006 tilsvarte ca 2,4 prosent av arbeidsstyrken. Samlet utgjorde antallet utstedte tillatelser i Norden i 2005 et tilskudd på ca 0,4 prosent av den nordiske arbeidsstyrken. I 2006 ser det ut til at nettobeholdningen av registrerte individuelle arbeidsmigranter fra EU-8 i Norden vil svinge mellom rundt 20,000 og rundt 50,000 gjennom året - eller mellom 0,2 og 0,4 prosent av den samlete nordiske arbeidsstyrken.

(42) Selv om et slikt omfang er høyere enn ventet, er nettomobiliteten klart mindre enn innen Norden og de årlige svingningene i den nordiske arbeidstyrken. Hvis man antar at retningen og styrken på migrasjonsstrømmene vil variere med konjunkturene, slik man har vært vant til innen Norden, og man antar at den intra-nordiske mobiliteten vil dempes av demografiske grunner, vil en netto arbeidsinnvandring i denne størrelses-

\footnotetext{
${ }^{27}$ I følge SSB (30.3.06) stod personer fra EU-8 for 22 prosent av nettoinnvandringen i 2005, 'Høyeste nettoinnvandring noensinne' (30.3.05); http://www.ssb.no/emner/02/02/20/innvutv/ se Tabell 9.
} 
orden neppe skape ubalanser i arbeidsmarkedene og representere et velkomment tilskudd til den aldrende nordiske arbeidsstyrken i årene framover. Hvis en videre antar at den sterke veksten de to første årene er uttrykk for en slags ‘åpningsbølg0〉 som etterhvert vil flate ut - også fordi økt velstandsvekst, aldring, og knapphet på arbeidskraft vil gjøre seg mer gjeldende i senderlandene og konkurransen om arbeidsinnvandrerne vil øke i Europa - er det grunn til å anta at arbeidsinnvandringen fra EU-8 i liten grad kan bidra til å løse de nordiske landenes problemer med knapphet på arbeidskraft i årene framover (Stien mfl 2006). Hvis en alternativt legger til grunn at de nordiske arbeidsmarkedene, som følge av langt høyere lønnsnivå og bedre sysselsettings- og karrieremuligheter, vil fortsette å trekke til seg stadig flere arbeidssøkere fra Polen og Baltikum selv om forholdene bedrer seg i hjemlandene - kan man imidlertid stå overfor et scenarie med varig høyere arbeidsimmigrasjonen enn man tidligere har vært vant til i Norden. I så fall vil det i de mest populære mottakerlandene stille krav om en mer aktiv, målrettet integrasjonspolitikk for disse gruppene. En hovedkonklusjon i den nordiske kontaktgruppens arbeid så langt er likevel at den individuelle arbeidsmigrasjonen i stor grad ser ut til å være etterspørselsdrevet og tilpasse seg behovene i mottakerlandenes arbeidsmarked. I et slik perspektiv er det grunn til å anta at heller ikke et scenarie med noe høyere arbeidsinnvandring vil skape sysselsettingspolitiske ubalanser i de nordiske landene.

(43) Den registrerte individuelle arbeidsmigrasjonen utgjør imidlertid bare en del av de samlete arbeidsvandringene fra EU-8. I tillegg kommer arbeidsmobiliteten knyttet til fri bevegelse av tjenester og sysselsetting i den private husholdssektoren. Det samlete omfanget av disse formene for mobilitet er ukjent, men mye tyder på at volumet kan være sammenliknbart med den registrerte individuelle migrasjonen. I Finland og Island antar myndighetene at tjenestemobiliteten de to første årene har vært klart større enn bevegelsen av arbeidstakere, mens myndighetene i Danmark antar at tjenestemobiliteten er noe lavere, og situasjonen i Sverige er uklar. Svensk LO antar likevel at antallet utstasjonerte arbeidstakere er høyere enn antallet ordinære arbeidsmigranter. I Norge viser flere surveys at omfanget av utstasjonering i bygg- og anlegg og industrien - to av de største brukerne av arbeidskraft fra EU-8 - er langt høyere enn omfanget av direkteansatte, mens situasjonen er omvendt i privat tjenesteyting og landbruk. På basis av vurderinger fra bransjeaktører og Fafos bedriftssurvey er det ikke urealistisk å regne med at det i 2006 befinner seg mellom 20 og 30,000 utstasjonerte arbeidstakere i norsk industri og byggebransje. Formålet her er ikke å gi et eksakt estimat, men å peke på at det i tillegg til en nettobeholdning på 20-50,000 individuelle arbeidsmigranter i Norden trolig befinner seg en beholdning av tjenesteytere av bortimot tilsvarende omfang. I Norge og Island innebærer det at de legale arbeidsmigrantenes andel av arbeidsstyrken sannsynligvis nesten kan dobles, og samlet utgjør over 3 prosent i Norge og over 5 prosent på Island. 
Andelene er markant lavere i de andre nordiske landene og for Norden som helhet (ca 0,5-1 prosent). I tillegg kommer en ukjent men ikke ubetydelig strøm av uregistrerte migranter som er sysselsatt i den private husholdsektoren.

(44) Oppsummert gir de overnevnte hovedtendensene et svært sammensatt bilde av arbeidsmigrasjonen til Norden de første to årene etter EU-utvidelsen. Samlet sett er arbeidsmigrasjonen til Norden moderat, men den nasjonale fordelingen av strømmene tegner et polarisert bilde: Sverige og Danmark framstår som mottakerland med lav tilstrømming (dog er det tegn på at tilstrømningen til Danmark blir vesentlig større i 2006, enn den var i 2005), Norge og Island framstår med høy tilstrømming både av arbeidssøkere og tjenesteytere, mens Finland befinner seg i en mellomstilling med høy tjenesteinnvandring og lav regulær arbeidsinnvandring. Landenes ulike overgangsordninger har tilsynelatende hatt liten innvirkning på totalvolumet av arbeidsmigrasjon, og har først og fremst påvirket fordelingen mellom arbeidsmigrasjon og tjenestemobilitet. Spesielt i land som har hatt restriktive overgangsordninger (behovsprøving) - som Finland og Island - har dette innebåret en sterk vridning mot tjenestemobilitet, hvilket er en av hovedgrunnene til at nettopp disse landene valgte å oppheve overgangsordningene fra 1.mai 2006. Landene ønsket mer regulær arbeidsinnvandring.

(45) Konsekvensene av den økte arbeidsmobiliteten til Norden synes så langt i hovedsak å være positive. I en periode med sterk etterspørselsutvikling i alle de nordiske land har det økte tilfanget av arbeidskraft medvirket til å øke vekstkapasiteten, dempe kostnadsveksten, bremse renteoppgangen, og øke handlefriheten i den økonomiske politikken. Ved å løse opp flaskehalser i en situasjon med tiltakende knapphet på arbeidskraft i en del markeder, har migrasjonen bidratt til å «smøre arbeidsmarkedet> og øke sysselsettingen også for innlendinger, mens ledigheten har gått ned. Med det høye innslaget av kortvarig migrasjon og tjenestemobilitet har arbeidstakerne fra EU-8 i stor grad fungert som en «ekstra reserve〉 av midlertidig arbeidskraft og bidratt til å øke 〈volum〉-fleksibiliteten i bedriftenes arbeidsstokk. Ved siden av denne funksjonen som arbeidskraftsreserve i en høykonjunktur, er det mye som tyder på at arbeidskraften fra EU-8 har gitt en del bedrifter økt fleksibilitet både når det gjelder arbeidstid og lønnskostnader. Dette kommer klart fram i Fafos undersøkelse blant norske bedrifter, ikke bare når det gjelder utstasjonert og innleid arbeidskraft fra EU-8, men også blant en betydelig del av bedriftene som har ansatt nye EU-borgere under overgangsordningens vilkår om gjengse norske lønns- og arbeidsvilkår (Dølvik mfl 2006). Det er således en vanlig vurdering blant økonomer at den økte konkurransen og arbeidsmobiliten fra EU-8 er en av hovedforklaringene på at lønnsveksten under de siste årenes høykonjunktur i Norge var den laveste på ti år i 2005. 
(46) På tross av det positive helhetsbildet som er tegnet over, er det klart at en såvidt hurtig vekst $\mathrm{i}$ arbeids- og tjenestetilbudet fra land med langt lavere lønns- og inntektsnivå enn i Norden, ikke er problemfri. I tidligere rapporteringer fra prosjektet er det pekt på at særlig tjenestemobiliteten er konsentrert til enkelte regioner, bransjer og yrker med sterk vekst. Selv om mobiliten samlet ikke er så stor, innebærer dette at både volumet og vilkårene knyttet til tilbud av utenlandsk arbeidskraft og tjenester i enkelte delmarkeder - f.eks. innen byggenæringen - har gitt grobunn for useriøs virksomhet, uønsket konkurransevridning, press på priser og sosial dumping. Ved siden av omgåelse av lov- og avtaleverk knyttet til ansettelser, lønns- og arbeidsvilkår, HMS-bestemmelser, skatter og avgifter - som rammer både samfunnsmessige fellesinteresser og seriøse bedrifter - har dette på enkelte områder bidratt til å sette normer og standarder forbundet med de nordiske arbeidslivsmodellene under press. I den grad det i enkelte bransjer vokser fram et sekundærarbeidsmarked på siden av det organiserte arbeidslivet, er dette ikke bare en utfordring for konkurrerende nasjonale bedrifter og arbeidstakere. Dersom økt tilbud av billige underentreprenører og arbeidstakere fører til et skift i konkurransevilkårene i en bransje, kan det bidra til endringer i bedriftenes arbeidskraftsstrategier og føre til mer outsourcing, økt andel atypiske tilknytningsformer og sterkere skiller mellom kjerne- og periferiarbeidskraft, dvs et mer segmentert innenlandsk arbeidsmarked. Økende aksept av lavlønnskonkurranse innenfor høykostsamfunn som de nordiske kan dermed gi grunnlag for større ulikheter i sysselsettingsmuligheter og gjøre det vanskeligere for utsatte grupper å bli inkludert i arbeidslivet, som i Norden er en kritisk forutsetning for å sikre tilstrekkelig tilgang på arbeidskraft i årene framover. Mens yrkesgrupper som besitter komplementær kompetanse til det nye tilbudet av arbeidskraft som regel vil tjene på $ø k t$ arbeidsmigrasjon, tyder internasjonal forskning på at yrkesgrupper med lik/konkurrerende kompetanse med arbeidsmigrantene ofte kan komme dårligere ut lønns- og/eller sysselsettingsmessig. ${ }^{28}$ Likevel, i tider med oppgang og utsikter til knapphet på arbeidskraft kan arbeidsmigrasjon bidra til høyere vekst og bedre sysselsettingsmuligheter enn hva som ellers hadde vært mulig for de fleste grupper, mens forholdet mellom vekst- og fortrengningseffekter for ulike grupper kan se annerledes ut i nedgangstider. Hittil tyder de fleste rapportene på at den dominerende delen av arbeidsmobiliteten fra EU-8 har funnet sted innen yrker/bransjer med relativt små krav til formell kompetanse; brorparten er sysselsatt i jobber for ufaglært og faglært arbeidskraft, og svært få i mer kompetansekrevende jobber. Dette har trolig sammenheng med den internasjonalt sett komprimerte lønnsstrukturen i nordiske land, som innebærer at lønningene er særlig høye i lite kompetansekrevende yrker, sammenliknet med

\footnotetext{
${ }^{28}$ Foreløpige beregninger fra et prosjekt utført av Marianne Røed (2006) ved Institutt for samfunnsforskning (ISF) i Oslo, kan tyde på at et liknende mønster kan spores i historiske norske registerdata.
} 
senderlandene og alternative destinasjonsland. I tillegg har overgangsordningene bidratt til å sikre at mange har fătt lønn i tråd med gjengs standard i vertslandet.

(47) Kjernen i striden om hvilke krav de nordiske land i fortsettelsen skal stille til lønns- og arbeidsvilkår for migranter fra nye EU-land - enten de kommer tjenesteveien eller blir ansatt i nasjonale bedrifter - gjelder ikke spørsmålet om å beskytte innenlandske arbeidstakere mot konkurranse eller å hindre utenlandsk arbeidskraft i å finne et bedre utkomme enn de kan gjøre hjemme. Striden handler først og fremst om virkemidlene for å sikre inkludering på likeverdige vilkår og motvirke framvekst av en ny underklasse, som uten adekvate tiltak dels kan bli definert etter etniske, nasjonale skillelinjer, og som følge av det, dels etter ferdigheter, helse og yteevne i den innenlandske arbeidsstyrken. Prinsipielt handler det altså om hva slags arbeidsliv man ønsker å utvikle, og vilkårene for inkludering. Det er i lys av slike betraktninger og vertslandenes legitime interesse i å beskytte sine sosiale standarder og arbeidslivsregimer mot regimekonkurranse, en må forstå at EU har knesatt vertslandsprinsippet som norm for fastsettelse av lønns- og arbeidsvilkår for utstasjonert arbeidskraft. Vilkårene for bruk av utenlandsk arbeidskraft kan også ha implikasjoner for næringslivets strategier for å utvikle verdiskapingen og konkurranseevnen. Et tilbudsskift som fører til økt innenlandsk bruk av lavkostoperatører kan nok styrke den enkelte bedrifts lønnsomhet på kort sikt, men kan i de mest utsatte bransjene på lengre sikt ha negative konsekvenser for utviklingen av faglært kompetanse, rekrutteringen av innenlandsk arbeidskraft, og innebære en vridning mot mindre produktive/mer arbeidsintensive produksjonsformer. Et slikt scenario samsvarer ikke så godt med det nordiske credoet om å velge «the high road til global konkurranseevne, gjennom økt satsing på innovasjon, kompetanse, kvalitet og produktivitet.

(48) Etter vår vurdering bør agendaen for den videre diskusjonen om utfasing av overgangsordningene og tilpasning av regimene for regulering, kontroll og håndheving av tjenestemobiliteten i Norden ta utgangspunkt i slike langsiktige vurderinger av hvordan vilkårene for økt arbeidsmigrasjon kan påvirke arbeidsmarkedets virkemåte, bedriftenes konkurranseforhold og arbeidskraftsstrategier, lønnsdannelsen, lagdelingen og vilkårene for sosial inklusjon. I den tidligere rapporteringen fra prosjektet har vi i dette perspektivet pekt på de uheldige virkningene av ulike vilkår for arbeidsmigrasjon og ulike lønns- og arbeidsbetingelser knyttet til bevegelse av tjenester og arbeidskraft. Finland har tatt konsekvensene av dette, opphevet restriksjonene på bevegelse av arbeidskraft og innført omfattende lovgivning og tiltak for å sikre likeverdige vilkår for utstasjonert arbeidskraft. Hvorvidt dette vil føre til en mer balansert utvikling i forholdet mellom arbeids- og tjenesteflyt gjenstår likevel å se, og vil bl.a. avhenge av om tiltakene for å kontrollere og håndheve rettighetene for utstasjonerte arbeidstakere lykkes. Som nevnt er det i tre- 
kantspillet mellom f.eks byggherrer, oppdragsgivere og utenlandske underentreprenører betydelige økonomiske fristelser knyttet til å omgå vertslandets regelverk. Og selv om aktørene følger spillereglene til punkt og prikke, vil det likevel være viktige, positive incentiver til å hyre underentreprenører fra EU-8 framfor å benytte direkteansettelser i egen bedrift: Tilgang til spesialisert kompetanse i forhold til det aktuelle oppdraget, økt fleksibilitet, sterkere kostnadskonkurranse - EU-8-firma vil gjerne ha lavere overhead-kostnader, skatt og avgiftsbyrde - samt mindre usikkerhet enn ved ansettelser. Det er derfor langt fra sikkert at en utjevning av de faktiske konkurransevilkårene og sikring av ryddige forhold vil føre til et markant skift i tjenestemobiliteten. Fordelingen av gevinster, tap og sosiale risikoer vil imidlertid endres kraftig, i favør av arbeidstakerne og senderlandene, som vil motta økte inntekter og skatte-provenue. Gitt likeverdige konkurransevilkår, vil økt tjenestemobilitet følgelig ha mange gunstige sider både fra vertslands- og senderlandssynspunkt; i tillegg til økt arbeidsmarkedsfleksibilitet på begge sider, er det rimelig å anta at vilkårene for kompetansesirkulasjon, overføring og læring over landegrensene på mange måter er bedre enn ved varig arbeidsmigrasjon, som innebærer en større risiko for 〈brain-drain〉 og mindre umiddelbare økonomiske tilbakeføringer til opprinnelseslandene. For mottakerlandene vil de potensielle kostnadene ved integrasjon, familiegjenforening, og tilknyttete velferdsytelser være lavere (likeså skatteinngangen), samtidig som arbeidsmarkedstilpasningen er momentan og de langsiktige spørsmålene om matching av tilbud og etterspørsel i arbeidsmarkedet dermed mindre aktuelle, slik det nordiske markedet i mange henseende har fungert. Det er dermed mange vektige grunner til å utvikle regulerings- og kontrollregimer som sikrer at den voksende tjenestemobiliteten til Norden kommer inn i ryddige og legitime former. Hvis man lykkes med det, vil man også skape grunnlag for mer rasjonelle økonomiske beslutninger i bedriftene om bruk av utenlandsk arbeidskraft og en mer balansert debatt om hva slags arbeidsmigrasjon som er mest hensiktsmessig for å løse ulike typer arbeidsmarkedsproblemer - både i mottaker- og senderland og om hvordan landene kan utvikle mer målrettete virkemidler for å legge til rette for de ønskete mobilitetsformer. (Hittil må man dessverre konstatere at slike diskusjoner i betydelig grad har druknet i strid og debatter om defensiv begrensning av de negative sidene ved den plutselige migrasjonen etter utvidelsen.) I en slik ramme kan man anta at arbeidsmigrasjonen vil bli gjenstand for mindre uro i bedriftene og mellom partene i arbeidslivet, og at vilkårene for samarbeid med senderlandene om tiltak for å fremme og kontrollere ønskelig mobilitet styrkes, slik man har tradisjon for i det nordiske arbeidsmarkedet. Et positivt scenario kan således være at arbeidsmarkedet i Østersjøregionen på sikt kan utvikle seg til å fylle tilsvarende funksjoner som det nordiske arbeidsmarkedssamarbeidet har gjort hittil. 
(49) De nordiske landene står overfor ulike utfordringer når det gjelder å implementere EU’s utstasjoneringsdirektiv og sikre utstasjonert arbeidskraft likeverdige vilkår med vertslandets arbeidstakere. I Finland og på Island, hvor man i prinsippet har heldekkende og stringente regimer, er hovedoppgaven å sikre effektiv håndheving og kontroll. Utfordringene er størst i Norge, hvor tilstrømmingen er høyest og allmenngjøring av tariffavtaler forutsetter at en av arbeidslivets parter ønsker allmenngjøring, kan bevise at forskjellsbehandling allerede har funnet sted, og får tilslutning i Tariffnemnda. Hittil har dette nesten bare skjedd i byggfagene, men utstasjonering brer om seg også i andre bransjer bl.a. industrien - ikke sjelden under vilkår som etter nasjonale standarder vil betegnes som sosial dumping. Den autonome, avtalebaserte modellen i Danmark og Sverige ser i hovedsak ut til å ha fungert etter hensikten, selv om fagforeningenes gjennomføringsansvar er meget ressurskrevende og legitimitetsutsatt, og det private husholdsmarkedet kan bli en voksende arena for useriøse aktører. Laval/Vaxholmsaken representerer en viss usikkerhetsfaktor, men ventes ikke å få dramatiske konsekvenser for den svenske modellen. Det sentrale spørsmålet i den nordiske diskusjonen framover er ikke hvilket system som er mest effektivt, men hvordan landene i lys av styrker og sårbarheter ved sine ulike regimer kan utvikle et helhetlig sett av virkemidler for implementering, kontroll og håndheving som sikrer troverdighet, treffsikkerhet og legitimitet for aktørene ute i felten. Her er det mye å lære av hverandres erfaringer. Finland er åpenbart i front når det gjelder å utvikle redskap for kontroll og håndheving, men resultatene avhenger av den praktiske iverksettingen, som stiller store krav til ansvarsmobilisering, holdninger og samarbeid mellom bedriftene, partene, brukerne, ulike myndighetsinstanser og offentligheten. Slik sett dreier utviklingen av de nasjonale regimene seg mindre om de reguleringstekniske redskapene, enn om evnen til å skape samfunnsmessig oppslutning om et sett av klare normer - understøttet av sanksjoner - og holdninger og prioriteringer som styrker arbeidslivets evne og vilje til å holde orden i egne rekker. I så måte har politikerne en viktig signalpolitisk rolle i å skape økt bevissthet om den samfunnsmessige betydningen av et åpent, velorganisert og inkluderende arbeidsliv bygd på likebehandling uansett nasjonalitet. EU’s fokusering på økt mobilitet, gjennomføringen av tjenestedirektivet og evalueringen av utstasjoneringsdirektivet, innebærer også at det kommende året vil være en besøkelsestid for å reise de nordiske perspektivene på disse spørsmålene på europeisk plan og påvirke de politiske og rettslige spillereglene i det voksende europeiske arbeids- og tjenestemarkedet.

(50) Det første året etter utvidelsen var den offentlige debatten i de fleste nordiske landene fokusert på overgangsordninger og kontroll med vilkårene for individuell arbeidsmigrasjon, mens det var relativt mindre oppmerksomhet om vilkårene for tjenestemobilitet. Med utfasingen av overgangsordningene og skjerpet fokus på tiltak mot omgåelser og sosial 
dumping i tjenestemarkedene, er situasjonen nå på mange måter snudd på hodet. Erkjennelsen av at hovedproblemene ikke er knyttet til den individuelle migrasjonen, men til tjenestemobiliteten, bør likevel ikke innebære at man neglisjerer de utfordringene som i enkelte land kan oppstå ved utfasing av overgangsordningene. I land med tilnærmet full avtaledekning og/eller generell allmenngjøring av tariffavtaler - som Sverige, Finland og Island - vil fri bevegelse av arbeidstakere neppe skape særlige vansker knyttet til lønnsdiskriminering eller sosial dumping. Erfaringene fra Sverige er at legaliseringen har styrket arbeidsinnvandrernes stilling. I de øvrige landene vil et mulig skift fra tjeneste- til arbeidsmobilitet trolig i seg selv redusere omfanget av omgåelsesproblemer. I Danmark og særlig Norge - hvor avtaledekningen i privat sektor er lavere enn i Sverige (se Figur 3 og 4) og allmenngjøring ikke er vanlig - kan likevel utfasingen av overgangsordningenes (allmenngjøringsfunksjon overfor EU-8-borgere> skape nye utfordringer i enkelte bransjer. Spesielt i Norge, er betydelige deler av bedriftene i privat sektor ikke omfattet av tariffavtaler, særlig i tjenestebransjer hvor ansettelse av innvandrere er mest vanlig.

(51) Riktignok er EU's antidiskrimineringsdirektiv innført i arbeidsmiljølovgivningen i alle de nordiske land, men disse reguleringene gjelder kun forskjellsbehandling innen samme type yrke/stillinger innen den enkelte bedrift. Som en del av den individuelle arbeidsretten, kan brudd på disse bestemmelsene kun prøves ved at den enkelte arbeidstaker reiser klagesak i det sivile rettsapparatet. Tidligere erfaringer med at innvandrere ofte konsentreres i bestemte bransjer og bedrifter, gjerne uten fagorganisering - eks reingjøring, hotell- og restaurant - samt at nyansatte migranter sjelden har ressurser og krefter til tid- og kostnadskrevende rettssaker, kan så tvil om hvor effektive slike reguleringer vil være i å hindre lønnsdiskriminering blant nye innvandrere. En kan også se for seg framvekst av et nytt sjikt bedrifter som bygger sin konkurransestrategi på ensidig rekruttering av arbeidskraft fra de nye EU-landene og lav lønn. I Fafos bedriftsundersøkelse fant vi allerede nå, trass i overgangsregimet, et overraskende innslag av slike bedrifter med (midlertidig) ansatte fra EU-8, først og fremst Polen. Gitt de økonomiske forskjellene mellom landene og velferdsgevinstene knyttet til denne typen migrasjon, kan etablering av slike bedrifter være en smidig måte å organisere migrasjonsnettverk og springbrett inn i de nordiske arbeidsmarkedene, som lett kan kombineres med oppdrag i husholdssektoren, underentrepriser og arbeidsutleie. På samme måte som i de flyktige markedene for underentrepriser og tjenestemobilitet, kan slike «etniske» småbedrifter være vanskelige å følge opp for fagforeningene og tilsynsmyndighetene som ofte må prioritere innsatsen om de store og økonomisk betydningsfulle bedriftene.

(52) I Finland og Island, hvor man har et lovhjemlet minstelønnsregime, reiser utfasingen av overgangsordningene først og fremst nye oppgaver knyttet til kontroll, håndheving og overvåking. Fagforeningenes opp- 
gave vil primært være rettet mot å orientere myndighetene, informere arbeidstakerne om deres rettigheter og hjelpe dem å hente ut deres lovfestete 〈goder〉. Innenfor de allmenngjorte områdene i byggebransjen i Norge har fagforeningene erfart at denne «advokat>-rollen både har gitt lettere kontakt, tillitt og nye medlemmer blant arbeidstakere fra EU-8. I Sverige og Danmark står fagforeningene overfor en mer sammensatt oppgave, idet de både skal spore opp bedriftene og forhandle fram avtaler, om nødvendig ved stridstiltak, som av og til også kan innebære en belastning for arbeidstakerne og en viss risiko for å miste jobben/oppdraget. I det danske tjenestemarkedet har fagforeningenes rolle som håndhevingsinstans gitt dem sterk profilering og bidratt til vitalisering av tillitsmannsapparatet rundt den halvoffentlige rollen som ivaretaker av den «danske modellen〉. Dobbeltrollen som 〈lønnspoliti〉, organisator og støttegruppe for sårbare arbeidsmigranter har imidlertid også innebåret utfordringer når det gjelder å forklare og vinne forståelse for fagforeningenes funksjon overfor utenlandske arbeidstakere som kan komme i krysspress mellom lojaliteten til sin nasjonale arbeidsgiver, ønsket om beholde jobben/oppdraget, og kravet om solidaritet med danske arbeidstakere i kampen mot sosial dumping. Styrken i den danske - og svenske - modellen er imidlertid at den sikrer forankring av ansvaret for håndheving av nasjonale lov- og avtaleverk hos partene og integrerer denne aktiviteten i det løpende partssamarbeidet. Dermed sikrer den også bevisstgjøring, synliggjøring og mobilisering «nedenfra) omkring den omforente topp-politiske konsensusen om å sikre likeverdige vilkår for arbeidsmigranter, som i ethvert system vil være en avgjørende forutsetning for et effektivt håndhevingssystem. Vilkåret for at fagforeningene skal klare å fylle sin nøkkelrolle i et slikt regime er imidlertid at de får tilstrekkelig legitimitet og oppbacking for de belastende oppgavene de påtar seg fra de politiske myndighetene og de øvrige aktørene i arbeidslivet. Tvetydigheter, distansering eller ansvarsfraskrivelse fra de øvrige aktørene i trepartssamarbeidet om å forsvare den nasjonale modellen kan fort underminere troverdigheten og effektiviteten i systemet.

(53) I betydelige deler av det norske arbeidsmarkedet, samt i de delene av det danske arbeidsmarkedet som ikke er omfattet av tariffavtaler, vil imidlertid situasjonen etter utfasingen av overgangsordningene være annerledes. Uten referanse til en lovfestet minstelønn, allmenngjorte tariffavtaler, eller en generelt gjeldende tarifflønn på området, kan organiserings- og forhandlingsoppgavene knyttet til å motvirke framvekst av et lavlønnssegment blant arbeidsmigranter fra EU-8 bli krevende. I Norge er fagforeningenes innflytelse på lønnsdannelsene i enkelte segmenter av servicearbeidsmarkedet med høy andel innvandrere og ungdom allerede sterkt svekket. I forbindelse med utfasingen av overgangsordningen aktualiserer det behovet for debatt om hvordan partene og myndighetene i fellesskap kan utvikle tiltak og incentiver for å styrke organisasjons- og avtaledekningen i de mest utsatte delene av arbeidsmarkedet. Dette an- 
svaret hviler selvsagt tyngst på partene, men historisk erfaring indikerer at den utfordringen vanskelig kan takles uten støtte fra en aktiv statlig tredjepart. I en tid hvor den nordiske modellen profileres som et forbilde i Europa vil det ikke være urimelig om myndighetene påtar seg et vesentlig medansvar for å sørge for at godene av denne modellen også gjøres effektivt tilgjengelig for arbeidstakere fra fattigere europeiske naboland. Dersom det likevel skulle vise seg at partene ikke lykkes med å sikre tilstrekkelig avtaledekning og likeverdige lønns- og arbeidsvilkår i de delene av arbeidsmarkedet hvor migrantene fra nye EU-land finner sysselsetting, vil myndighetene og partene måtte lete etter nye grep for å ruste opp de nasjonale modellene til å tåle presset fra et åpent og voksende europeisk arbeidsmarked. I så fall er det per i dag vanskelig å se at det kan gjøres uten å vurdere utvikling av nye og mer effektive minstelønnsregimer i de aktuelle bransjene, som trolig vil forutsette et samspill mellom lov- og avtaleregulering. Både i Danmark og Norge anser store deler av fagbevegelsen enhver lovhjemling av spørsmål knyttet til lønnsdannelsen som en trussel mot viktige grunnprinsipper i de nasjonale modellene. Hvilke løsninger som kan avtegne seg dersom vernet av disse grunnprinsippene kommer i konflikt med et annet aksiom i modellene - kravet om lik lønn for likt arbeid - skal vi ikke spekulere i her. I en slik situasjon vil man imidlertid ha nyttig erfaringsmateriale å trekke på fra andre nasjonale varianter av de nordiske modellene.

(54) I dette notatet har vi skissert en del temaer og problemstillinger som vi gjennom arbeidet i prosjektets nordiske kontaktgruppe har identifisert som sentrale på den arbeidslivspolitiske agendaen knyttet til EUutvidelsen:

- Skape mer likeverdige/konkurransenøytrale vilkår for arbeidsmobilitet tjenesteveien og via det ordinære arbeidsmarkedet;

- Videreutvikle de nasjonale regimene for regulering av lønns- og arbeidsvilkår for utstasjonerte arbeidstakere (implementering av utstasjoneringsdirektivet)

- Forbedre de nasjonale regimene for overvåkning, kontroll, håndheving og sanksjoner;

o Utvikle mer effektive ordninger for registrering og/eller deklarering av utstasjonerte arbeidstakere, som er et avgjørende vilkår for håndheving

o Utvikle et bedre, sammenliknbart statistikkgrunnlag

o Klargjøre vilkårene for innsyn i lønns- og arbeidsvilkår hos underentreprenører og utleiefirma

o Videreutvikle byggherreansvaret og bestillerrollen, inklusive offentlige anbudsregler

o Tilpasse regelverket for vikar/bemanningsbyråer til et åpent arbeidsmarked 
o Styrke de offentlige tilsynsfunksjonene ved å utvikle kompetanse, koordinering og administrativt samarbeid med nabo- og senderland

o Utvikle sanksjonsformer som har en reell allmennpreventiv effekt

o Vedlikeholde og videreutviklede nasjonale parts-og avtalesystemene

o Påvirke europeiske vilkår og spilleregler for kontroll og håndheving

- Vurdere behovet for tiltak for å motvirke forskjellsbehandling og framvekst av et lavlønnssegment i arbeidsmarkedet etter utfasingen av overgangsordningene.

Selv om de nordiske landene har forskjellige ordninger og tradisjoner på en del områder, er utfordringene og grunnforutsetningene i stor grad felles. Vi er overbevist om at aktørene har mye å lære av hverandre ved systematisk utveksling av informasjon, kunnskap og erfaringer med ulike tiltak på feltet. Poenget er neppe å drive ‘benchmarking) eller jakt på 〈best practice〉 på ulike delområder, men å bruke hverandres erfaringer til å klarlegge handlingsrom og alternativer med sikte på å utvikle en best mulig sammenheng mellom kjeden av nasjonale reguleringer, virkemidler og tiltak. En kritisk faktor i tiltakskjeden er evnen til overvåkning, kontroll og håndheving av spillereglene. Disse spørsmålene vil stå i fokus for arbeidet i dette prosjektet det kommende året. Her er kanskje den viktigste utfordringen å få til en målrettet koordinering, samarbeid og ansvarsmobilisering mellom de involverte offentlige og sosiale aktørene på feltet. Det gjelder ikke bare på nasjonalt og nordisk plan, men også i forhold til de nye EU-landene og for å påvirke utviklingen på europeisk plan. 



\section{Executive Summary}

(1) Two years after the enlargement of the EU a certain pattern has emerged in the labour migration streams from the new EU member states to the Nordic countries. Individual labour migration has varied strongly among the Nordic countries, but continues to grow. By meeting growing demand for labour, the movement of labour has contributed to increasing production and employment, curbing prices and interest rates, and extending the room of manoeuvre in economic policies. Growth has been strongest in Norway and Iceland, while Finland and Sweden have seen a certain decline in registered migration. No signs of social tourism have been detected. Labour mobility related to services has increased strongly, and seems to clearly exceed regular labour migration in key sectors. This development has given rise to new challenges in terms of regulation, control and enforcement.

(2) In the same manner as most of the «old s EU member states, Denmark, Finland, Iceland and Norway chose to introduce transitional arrangements for the movement of labour from the EU-8. Sweden, and in practice also the United Kingdom and Ireland, opened their labour markets from day one. Finland, Iceland, Greece, Portugal and Spain repealed their transitional arrangements from 1 May 2006, and Italy followed suit. Denmark undertook a relaxation of its regime and made it possible to pre approve enterprises that have collective wage agreements, and will repeal its arrangement on 1 May 2009 at the latest, as will Norway. Also other EU member states have announced a gradual opening of the labour market in the coming years. With the exception of Austria and Germany, an open labour market will thus be established in the current EU/EEA area from 1 May 2009. There are indications, however, that several countries will make use of the right to establish transitional arrangements if/when Bulgaria and Romania join the EU.

(3) The Nordic experience has highlighted the difficulties involved in having separate regimes for individual labour migration on the one hand, and labour mobility through services on the other. Differences in the conditions for wage setting, labour conditions, taxation/duties, control and enforcement have given rise to strategic circumventions and distortions. These have contributed to a reduction of regular labour immigration and to distortions of competition, dumping of wages and creation of disorderly conditions in parts of the labour and service markets. Signs of growing illegal employment of immigrants have also been noted, not least in the household sector.

(4) Following a phasing out of the transitional arrangements, the legal opportunities for employment of workers from the EU-8 in enterprises 
that pay wages below the national rate are expanded. Especially in countries/sectors that have limited coverage of collective wage agreements and/or no provisions for generalisation of wage agreements or statutory minimum wages, this may give rise to differential treatment, increased low-wage competition and strains on wages, working conditions and collective agreements. Abolition of controls at the border will serve to increase the requirements to be fulfilled by the internal regime for regulation and control in the labour market. One challenge is to develop policies that can ensure equal terms for service and labour migration, equal treatment of foreign workers, and that takes account of - and can influence the conditions for free movement within the open European market.

(5) With their high level of welfare and aging populations, the Nordic countries are facing demanding dilemmas. The demand for labour is increasing, and is not likely to be covered from within the Nordic countries in the long term. The new EU members will see stronger tendencies towards aging, and their wage levels and affluence is increasing. In the coming years we are therefore likely to see a growing competition for labour in Europe and a seller's market for services. The demand for labour from third countries and the pressure along the outer rim of the EU can be expected to increase. These factors will strengthen the need for development of a more unified and long-term policy for labour and service mobility nationally, in the Nordic countries and at the European level. 


\section{Referanser og kilder}

Ahlberg, K., Bruun, N. og J. Malmberg (2006), 'The Vaxholm case from a Swedish and European perspective.'I: Transfer-European Review of Labour and Research 2/2006

Arbejdsmarkedsstyrelsen i Danmark (2006), Notat. Bilag til møte i forligskredsen den 5. april 2006

ASI (2006), Icelandic Labour Law. A summary of basic rights and obligations in the Icelandic labour market. Icelandic Confederation of Labour. http://www.asi.is/upload/files/Icelandi c\%20labour\%20law3.pdf

Beskæftigelsesministeriet (2006), Registrering af udstationerede - inden for EU-rettens rammer. Notat 24.02.06.

Boeri, Tito og Herbert Brücker (2003), Potential Migration from Central and Eastern Europe - an update. (http://europa.eu.int/comm/ employment)

Bruun, Niklas (2006), Posting of workers: do the EU-rule work? A Nordic perspective. Mini-hearing, Europan Parliament, 20.04.2006

European Commission (2003) Report (...) on the implementation of the Directive 96/71/EC (...) concerning the posting of workers in the framework of the provision of services.

(2003) Communication (...): The implementation of Directive 96/71/EC in the Member States, COM (2003) 458 final.

(2006) Report in the Functioning of the Transitional arrangements set out on the 2003 Accession Treaty (period 1 May2004-30 - 30 April 2006).

(2006b) Guidance on the posting of workers in the framework of the provision of services, COM (2006) 159 final,

Cremers, Jan (2006), 'Free movement of services and equal treatment 0 workers: the case of construction'. I: Transfer- European Review of Labour and Research 2/2006
Dølvik, Jon Erik og Line Eldring (2006), 'Industrial relations responses to migration and posting of workers after EU enlargement: Nordic trends and differences'. I: Transfer-European Review of Labour and Research 2/2006

Dølvik, J.E., L. Eldring, J.H. Friberg, T. Kvinge, S. Aslesen og A.M. Ødegård (2006), EU-utvidelsen: Endringer i norske bedrifters arbeidskraftsstrategier? Fafo-notat 2006:14

Dølvik, Jon Erik og Line Eldring (2006), Statusrapport Januar 2006: EU-utvidelsen og konsekvensene for arbeidsmobiliteten til Norden. Halvårsnotat fra Arbeidsgruppe under Nordisk Ministerråds Arbeidsmarkedsutskott

Dølvik, Jon Erik og Line Eldring (2005), Arbeids- og tjenestemobilitet etter EU-utvidelsen. Nordiske forskjeller og fellestrekk. Sluttrapport for en arbeidsgruppe under Nordisk Ministerråd. TemaNord 2005:566

EU Commission (2006), Report on the Functioning of the Transitional Arrangements set out in the 2003 Accession Treaty (period 1 May 2004-30 April 2006), http://eur-lex.europa.eu/ LexUriServ/site/en/com/2006/ com2006_0048en01.doc

EU Commission (2006), Transitional measures for the free movement of the workers forming the subject of the accession treaty of 2003, Memo/06/176: http://www.europa. eu.int/rapid/pressReleasesAction.do?reference=MEMO/06/176\&fo $\underline{\text { rmat }=\text { HTML\&aged }=0 \text { \&language }=E N}$ \&guiLanguage $=$ no

European Foundation for the Improvement of Living and Working Conditions (2006), Temporary agency work in an enlarged European Union. Dublin. http://www.eurofound.eu.int/pubdocs/2005/139/en/1/ef05139en.pdf

Evju, Stein (2006), Evaluering av allmenngjøringsordningen - høring. 
http://odin.dep.no/filarkiv/269805/Evi u.pdf

Friberg, J.H. (2006), Individuell arbeidsinnvandring. Utfordringer to år etter EU-utvidelsen. Fafo Østforum/Fafonotat 2006:07

Erling Hjelmeng og Olav Kolstad (2005), Allmenngjøringsloven og innsynsrett -EØS-rettslige problemstillinger, http://odin.dep.no/filarkiv/ 269459/NHO_-_vedlegg.pdf

Lismoen, H. (2006), 'Low-wage regulation in Scandinavia'. I: Schulten, T. et al (ed.), Minimum wages in Europe. Brussels: ETUI-REHS

Maier, Lena (2005), Utstationering av arbetstagare och det svenska kollektivavtalssystemet. En rättslig analys. Stockholm: SACO

Ot.prp.nr. 92 (2005-2006), Om lov om endringer i lov 4. juni 1993 nr. 58 om allmenngjøring av tariffavtaler m.v. og lov 24. juni 1988 nr. 64 om utlendingers adgang til riket og deres opphold her (utlendingsloven). http://odin.dep.no/filarkiv/283827/Ot p0920506-TS.pdf

Røed, Marianne (2006), Foredrag om lønnsvirkninger av migrasjon, konferanse Norges Forskningsråds program for Arbeidslivsforskning, Voksenåsen 29.mai 2006.

Seriøsitet i byggenæringen (2004) http://www.fellesforbundet.no/upload /NYHETER/Svartvedlegg.pdf

SOU 2006:28, Nya upphandlingsregler 2 http://www.regeringen.se/content/ 1/c6/06/03/33/447d389e.pdf

SSB (2006) 'Høyeste nettoinnvandring noensinne', www.ssb.no/emner/ 02/02/20/innvutv

Statsrådet (2006), Redogörelse til riksdagen om verkningarna av lagen om övergangstid samt verkningarna av arbetskraftens och tänesterna fria rörlighet på arbetsmarknadsläget inom olika brancher. Finland

Stien, K., T. Lødemel og B. Johannesen (2006), 'Innvandring løser ikke problemet', Horisont - Næringspolitisk tidsskrift, NHO: Oslo.

Stokke (2005) Allmenngjøring og minstelønn i Norge og EU, Foredrag på seminar i Fafo Østforum 29.9.05, Oslo.

Stokke (2006) Allmenngjøring, minstelønn og innsynsrett i Norge og EU, Innledning på seminaret Allmenngjøring under press?, Institutt for privatrett, UiO 15. mars 2006, Oslo.

Stortingsmelding nr. 9 (2005-2006) Om overgangsordningane for arbeidstakarar frå dei nye EØS-landa mv.

Sveriges Ambassad, Dublin (2006), Promemoria 2006-06-16

Sveriges saksframlegg til EF-domstolen (2006), Regeringskansliet, Utrikesdepartementet, 2006-01-30.

UDI, 27.6.06 EØS-utvidelsen - tillatelser med formål arbeid.

UDI, Tall og fakta 1. tertial 2006 http://www.udi.no/upload/Statistikk/T allogfakta-1tertial06.pdf

Udlændingestyrelsen juni 2006, Familiesammenføringsansøgningsantal http://www.udlst.dk/NR/rdonlyres/e6 kr3ge46gzp36obsg2kgvmes7ahj4lqrp gowevsclj553ug6cemmug5c5ldnb7 lajjb7cjiqfyi2g5gwjhzzuemkae/Famili esammenføring!A1

Utrikesdepartementet (2006-01-30) Skriftlig yttrande. Mål C-341(05 Laval un Partnerei. Regeringskanseliet, Stockholm. 


\section{Vedlegg 1: Overgangsordningene i Norden}

Overgangsordninger i nordiske land for individuelle arbeidssøkere fra de nye EUlandene, per januar 2006

\begin{tabular}{|c|c|c|}
\hline LAND & OVERGANGSORDNINGER 1. mai 2004-31. april 2006 & $\begin{array}{l}\text { ENDRINGER I OVERGANGSORD- } \\
\text { NINGER ETTER 1. mai } 2006\end{array}$ \\
\hline Danmark & $\begin{array}{l}\text { Man kan reise til Danmark og søke arbeid for egen } \\
\text { regning i inntil } 6 \text { måneder. } \\
\text { Arbeidstakeren kan ikke begynne i jobben før det } \\
\text { foreligger en oppholds- og arbeidstillatelse. Slik tillatel- } \\
\text { se gis dersom det er tale om fulltidsarbeid på overens- } \\
\text { komstmessige eller sedvanlige lønns- og arbeidsvilkår } \\
\text { hos en arbeidsgiver som er inneholdelsespliktig etter } \\
\text { kildeskatteloven, og som ikke er omfattet av lovlig } \\
\text { konflikt. }\end{array}$ & $\begin{array}{l}\text { Overgangsordningen revidert: } \\
\text { Virksomheter som er omfattet av } \\
\text { kollektivavtale kan forhåndsgod- } \\
\text { kjennes til å ansette arbeidstake- } \\
\text { re fra EU-8. Arbeidstakere som } \\
\text { ansettes i disse bedriftene tren- } \\
\text { ger dermed ikke oppholds- og } \\
\text { arbeidstillatelse i forkant av } \\
\text { ansettelsen, men det skal meldes } \\
\text { fra om ansettelsesforholdet til } \\
\text { utlendingsmyndighetene i det } \\
\text { vedkommende begynner å } \\
\text { arbeide. Det gis videre større } \\
\text { muligheter for deltidsarbeid, } \\
\text { automatisk arbeidstillatelse } \\
\text { studenter fra EU-8, og rett til å } \\
\text { arbeide mens søknad om forlen- } \\
\text { get tillatelse behandles, og rett til } \\
\text { å arbeide for pendlere fra EU-8. }\end{array}$ \\
\hline Finland & $\begin{array}{l}\text { Arbeidskraftbyråene gir arbeidstillatelser. Følger sam- } \\
\text { me krav som utlendingsloven angir for personer utenfor } \\
\text { EØS. Behovet for arbeidskraft skal vurderes, og om } \\
\text { arbeidsinnvandreren fortrenger finsk arbeidskraft. Ved } \\
\text { søknad en må arbeidsgiveren legge ved en bekreftelse } \\
\text { på at arbeidsvilkårene er i tråd med gjeldende bestem- } \\
\text { melser og kollektivavtaler, ev. tilsvarer den praksis som } \\
\text { gjelder andre arbeidstakere i tilsvarende stillinger. } \\
\text { Dersom arbeidskraftsbyrået krever det, skal det også } \\
\text { legges ved en utredning om at arbeidsgiveren har } \\
\text { oppfylt og fortsatt vil oppfylle sine forpliktelser som } \\
\text { arbeidsgiver. Arbeidsgiveren skal oppbevare op- } \\
\text { plysninger om ansatte utlendinger og bakgrunnen for } \\
\text { deres arbeidstillatelse på arbeidsplassen (og i } 4 \text { år etter } \\
\text { at arbeidsforholdet er opphørt, slik at arbetarskydd- } \\
\text { myndighetene ved behov har enkel tilgang til op- } \\
\text { plysningene). Ingen arbeids- eller oppholdstillatelse } \\
\text { kreves for sesongarbeid i inntil } 3 \text { måneder i jordbruket }\end{array}$ & $\begin{array}{l}\text { Overgangsordningen avviklet. } \\
\text { Lag om registrering av uppgifter } \\
\text { om arbete som utförs av medbor- } \\
\text { gare i vissa av Europeiska unio- } \\
\text { nens medlemsstater trådte i kraft } \\
\text { 5. juni 2006, og gjelder til og med } \\
\text { 30. april 2009. } \\
\text { Lagförslag om beställarens } \\
\text { redogörelseskyldighet och ansvar } \\
\text { vid anlitande av utomstående } \\
\text { arbetskraft skal behandles av } \\
\text { Riksdagen. }\end{array}$ \\
\hline Island & $\begin{array}{l}\text { Opprettholder utlendingsloven for de nye EØS-land, og } \\
\text { de samme regler gjelder som før 1.mai. Arbeidsgiver } \\
\text { må søke om arbeidstillatelse innen arbeidstakeren } \\
\text { kommer til Island. Generelle arbeidsmarkedssynspunk- } \\
\text { ter skal gjelde, det vil si at det ikke skal forefinnes } \\
\text { arbeidstakere fra Island eller andre EØS-stater som kan } \\
\text { gjøre arbeidet. Det er en forutsetning for oppholdstilla- } \\
\text { telse at arbeidsdeltakelsen vil bidra til egen forsørgelse. }\end{array}$ & $\begin{array}{l}\text { Overgangsordningen avviklet. } \\
\text { Fram til 1. mai } 2009 \text { må arbeids- } \\
\text { giver innen } 10 \text { dager informere } \\
\text { Arbeidsdirektoratet om at de har } \\
\text { ansatt en person fra EU-8 og de } \\
\text { må legge ved en kopi av ar- } \\
\text { beidskontrakten, som skal ha } \\
\text { lønnsvilkår som fastsatt i lover og } \\
\text { overenskomster. }\end{array}$ \\
\hline
\end{tabular}




\begin{tabular}{|l|l|l|}
\hline Norge & $\begin{array}{l}\text { Man kan reise til Norge og søke arbeid for egen regning } \\
\text { i inntil } 6 \text { måneder. } \\
\text { Må ha oppholdstillatelse med adgang til arbeid før en } \\
\text { kan begynne å arbeide. Man kan søke om tillatelse ved } \\
\text { norske utenriksstasjoner i hjemlandet, og ved personlig } \\
\text { frammøte hos politiet i Norge. Arbeidsgiveren kan søke } \\
\text { på vegne av arbeidstakeren. }\end{array}$ & $\begin{array}{l}\text { Overgangsordningen videreført i } \\
\text { samme form. }\end{array}$ \\
$\begin{array}{l}\text { Det må foreligge et konkret tilbud om arbeid tilsvarende } \\
\text { fulltidsstilling. Lønns- og arbeidsvilkår skal være de } \\
\text { samme som for norske arbeidstakere i samme type } \\
\text { jobb (lønn i henhold til tariff eller det som er normalt for } \\
\text { vedkommende sted og yrke). Det må leveres ansettel- } \\
\text { sesbevis eller arbeidsavtale hvor arbeidsgiveren skriver } \\
\text { under på at lønns- og arbeidsvilkår er i tråd med regle- } \\
\text { ne. } \\
\text { Alle EøS-borgere som skal utføre et arbeid/yte en } \\
\text { tjeneste av en viss varighet skal registreres, men } \\
\text { ordningen er ikke iverksatt. }\end{array}$ & \\
\hline Sverige & $\begin{array}{l}\text { Ingen overgangsordning. (Ved opphold over 3 måneder } \\
\text { må det søkes om oppholdstillatelse. Det skal legges } \\
\text { ved ansettelsesbevis ved søknaden hvor opplysninger } \\
\text { om arbeidsforholdets lengde og form framkommer.) }\end{array}$ & Ingen overgangsordning. \\
\hline
\end{tabular}




\section{Vedlegg 2: Statistikk}

Tabell 1 Arbeidstillatelser til individuelle arbeidssøkere fra EU-8 i perioden 1. mai 2004 - 30. april 2006, etter nordisk mottakerland

\begin{tabular}{|c|c|c|c|c|c|c|}
\hline & $\begin{array}{l}\text { Kategori } \\
\text { tillatelserl } \\
\text { søknader }\end{array}$ & $\begin{array}{l}2003 \\
\text { (1.mai- } \\
\text { 31.desember) }\end{array}$ & $\begin{array}{l}2004 \\
\text { (1.mai- } \\
\text { 31.desember) }\end{array}$ & $\begin{array}{l}2005 \\
\text { Hele året }\end{array}$ & $\begin{array}{l}2006 \\
\text { 1. januar- } \\
\text { 30. april }\end{array}$ & $\begin{array}{l}\text { SUM } \\
\text { 1. mai } 2004- \\
\text { 30. april } 2006\end{array}$ \\
\hline Danmark & $\begin{array}{l}\text { Meddelte } \\
\text { oppholds- og } \\
\text { arbeidstilla- } \\
\text { telser }\end{array}$ & 776 & 2097 & 4923 & $\begin{array}{l}3651 \\
\text { (jan-mai) }\end{array}$ & 10671 \\
\hline Finland & $\begin{array}{l}\text { Arbetskrafts- } \\
\text { byråns beslut }\end{array}$ & 6747 & 2169 & 2633 & 803 & 5605 \\
\hline Island & $\begin{array}{l}\text { Innvilgete } \\
\text { arbeidstilla- } \\
\text { telser } \\
\text { (Temporary } \\
\text { work permits) }\end{array}$ & 230 & $\begin{array}{l}515 \\
\text { (+666 forny- } \\
\text { elser) }\end{array}$ & $\begin{array}{l}2764 \\
\text { (+844 forny- } \\
\text { elser) }\end{array}$ & $\begin{array}{l}2566 \\
(+1180 \\
\text { fornyelser) }\end{array}$ & $\begin{array}{l}5845 \\
(+2690 \\
\text { fornyelser) }\end{array}$ \\
\hline Norge & $\begin{array}{l}\text { Innvilgete } \\
\text { EØS- } \\
\text { tillatelser }\end{array}$ & $\begin{array}{l}12404 \\
\text { (+784 forny- } \\
\text { elser) }\end{array}$ & $\begin{array}{l}16975 \\
(+3558 \\
\text { fornyelser) }\end{array}$ & $\begin{array}{l}19301 \\
(+17902 \\
\text { fornyelser })\end{array}$ & $\begin{array}{l}5455 \\
(+5799 \\
\text { fornyelser) }\end{array}$ & $\begin{array}{l}41731 \\
(+27259 \\
\text { fornyelser })\end{array}$ \\
\hline Sverige & $\begin{array}{l}\text { Innkomna } \\
\text { nye EES- } \\
\text { ansökningar } \\
\text { arbete }\end{array}$ & 2096 & 3963 & 4805 & 1830 & 10598 \\
\hline Total & & $\begin{array}{l}22253 \\
\text { (+784 forny- } \\
\text { elser) }\end{array}$ & $\begin{array}{l}25719 \\
(+4224 \\
\text { fornyelser) }\end{array}$ & $\begin{array}{l}34426 \\
\text { (+18 } 746 \\
\text { fornyelser) }\end{array}$ & $\begin{array}{l}14305 \\
\text { (+6 979 } \\
\text { fornyelser) }\end{array}$ & $\begin{array}{l}74450 \\
\text { (+29 949 } \\
\text { fornyelser) }\end{array}$ \\
\hline
\end{tabular}

Kilder og presiseringer: Fornyete tillatelser kan både innebære forlengelse av nåværende tillatelse og tillatelser for migranter som innleder et nytt opphold i landet etter å ha hatt tillatelse tidligere og dermed befinner seg i registrene til utlendingsmyndighetene ('gjengangere').

Danmark: Arbejdsmarkedsstyrelsen/Udlændingestyrelsen. Tallet for 2003 gjelder hele året. For 2003 kan man ikke skille ut selvstendige næringsdrivende, men det antas at de ikke utgjør mange. Tallene inkluderer ikke fornyelser. Tallet for 2006 inkluderer mai måned.

Finland: Arbetsministeriet. Arbeid med under 3 måneders varighet i landbruket registreres ikke etter 1.5.2004. Etter at saksbehandlingen hos de finske arbeidskraftsbyråene ble overført til utlendingsmyndighetene har den statistiske oppfølgingen blitt vesentlig vanskeligere.

Island: Arbejdsmarkedsstyrelsen Island (Vinnumalastofnun). Tallet for 2003 er for hele året. I 2006 inkluderer tallet for nye tillatelser 2510 nye temporære arbejdstillatelser, 23 «specialisede tillatelser» og 33 «au pair-tillatelser». 2006-tallet for fornyelser inkluderer 911 forlengede tillatelser, 70 permanente tillatelser og 199 «nye arbejdsplasser» (omfatter personer som har skiftet arbeidsplass eller fått ny tillatelse).

Norge: Utlendingsdirektoratet (UDI). Det ble gitt 784 fornyelser i 2003 og 3558 fornyelser i 2004, vi vet ikke hvor mange av disse som ble gitt før 1.mai, men har her valgt å anta at de ble gitt etter 1.mai. 7493 av tillatelsene i 2004 hadde varighet over 3 måneder, for hele perioden (1.5.2004-31.12.2005) hadde 40 prosent av tillatelsene varighet over 3 måneder. I perioden 1. januar til 31. mai hadde 60 prosent av tillatelsen varighet over 3 måneder. Angående kategorien «fornyelser» etter 1.5.04: Fornyelse innebærer ikke nødvendigvis en sammenhengende forlengelse. Dersom en person reiser tilbake ti hjemlandet en periode, og deretter søker om ny arbeidstillatelse, vil dette bli kategorisert som «fornyelse» på lik linje som om personen hadde oppholdt seg sammenhengende i Norge. UDI presiserer at alle tall for 2006 er foreløpige.

Sverige: Migrationsverket. Inkluderer ikke arbeid med under 3 måneders varighet etter 1.5.2004. Inkluderer ikke fornyelser; totalt i perioden 1.5.2004 til 31.12.2005 ble det gitt 2261 «förlängninger» til alle grupper av søknader, men fornyelsene antas hovedsaklig å dreie seg om arbeidstakere og foretakere. Tallene omfatter søknader, ikke innvilgede tillatelser. Cirka 95 prosent av alle som søker får innvilget tillatelse. Personer med en ansettelse som gjelder inntil videre eller som gjelder ett år eller lenger, får en 5-årig tillatelse. De som har ansettelse for kortere enn ett år, får tillatelse med samme gyldighetstid som ansettelsen.

For alle landene: Tillatelsene fra 2003 har andre navn, ikke gjengitt her, men regnes som sammenliknbare med det som nå faller inn under EØS-kategorien (som har litt ulike betegnelser i de ulike landene). Sesongarbeid og arbeid under 3 måneder er inkludert der det er registrert. Ulikheter i registrering av arbeid under 3 måneder gir antakelig en del ukontrollerbare utslag. For alle tall tas det forbehold om at det kan være litt forskjell på kategoriene på grunn av ulike kilder. 


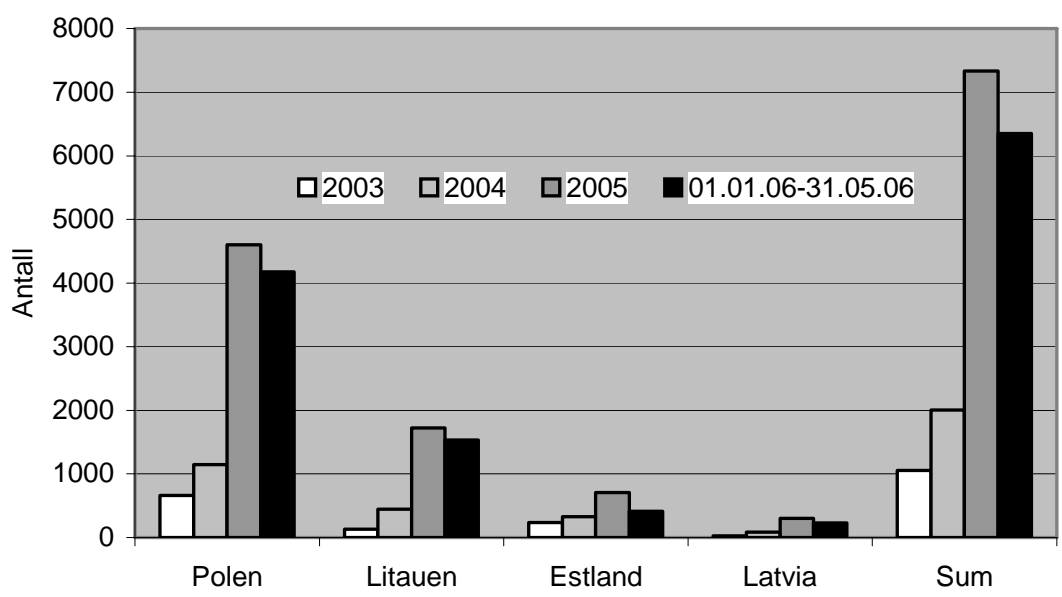

Figur 6 Registrerte arbeidstakere fra Polen og Baltikum i utenlandske virksomheter med oppdrag i Norge, 2003-31.05.2006 (Kilde: Skattekontoret for utenlandssaker) 


\section{Vedlegg 3: Liste over kontaktgruppens medlemmer}

Med en viss utskifting gjennom året, har følgende personer deltatt i kontaktgruppen:

\begin{tabular}{|c|c|c|c|}
\hline Navn & Postadresse & Telefon & E-post \\
\hline René Høyer Jørgensen & $\begin{array}{l}\text { Nordisk Ministerråd } \\
\text { Store Strandstræde } 18 \\
1255 \text { Kbh K, Danmark }\end{array}$ & +4533960360 & rhi@norden.org \\
\hline Ole Bondo Christensen & $\begin{array}{l}\text { Beskæftigelsesministeriet } \\
\text { Ved Stranden } 8 \\
1061 \text { København K }\end{array}$ & $\begin{array}{l}+4533927321 \\
\text { Fax: +33 } 121378\end{array}$ & obc@bm.dk \\
\hline Louise de Brass & $\begin{array}{l}\text { Beskæftigelsesministeriet } \\
\text { Ved Stranden } 8 \\
1061 \text { København K }\end{array}$ & +4533954473 & Idb@bm.dk \\
\hline Lisbet Møller Nielsen & $\begin{array}{l}\text { Beskæftigelsesministeriet } \\
\text { Ved Stranden } 8 \\
1061 \text { København K }\end{array}$ & +4533925892 & Imn@bm.dk \\
\hline Mirkka Mykkänen & $\begin{array}{l}\text { Arbetsministeriet } \\
\text { Postbox } 34 \\
\text { FIN-00023 } \\
\text { Government Finland } \\
\end{array}$ & $\begin{array}{l}+358916047019 \\
+358400703984 \\
\text { (mobil) }\end{array}$ & mirkka.mykkanen@mol.fi \\
\hline Olli Sorainen & $\begin{array}{l}\text { Arbetsministeriet } \\
\text { Postbox } 34 \\
\text { FIN-00023 } \\
\text { Statsrådet Finland } \\
\end{array}$ & +358106048022 & olli.sorainen@mol.fi \\
\hline Sinikka Hyyppä & $\begin{array}{l}\text { Arbetsministeriet } \\
\text { Postbox } 34 \\
\text { FIN-00023 } \\
\text { Statsrådet Finland }\end{array}$ & $\begin{array}{l}+358-9-106047 \\
019\end{array}$ & sinikka.hyyppa@mol.fi \\
\hline Gissur Petursson & $\begin{array}{l}\text { Vinnumålastofnun } \\
\text { Hafnarhúsinu } \\
\text { v/Tryggvagötu } \\
\text { 150 Reykjavik, Island }\end{array}$ & +3545154800 & Gissur.petursson@vmst.is \\
\hline Egill Heiðar Gíslason & $\begin{array}{l}\text { Vinnumålastofnun } \\
\text { Hafnarhúsinu } \\
\text { v/Tryggvagötu } \\
150 \text { Reykjavik, Island }\end{array}$ & & egill.gislason@vmst.is \\
\hline Anna Fanebust & $\begin{array}{l}\text { Arbeids- og sosialdeparte- } \\
\text { mentet } \\
\mathrm{Pb} 8019 \\
0030 \text { Oslo, Norge }\end{array}$ & +4722244723 & anna.fanebust@aid.dep.no \\
\hline Eli Mette Jarbo & $\begin{array}{l}\text { Arbeids- og sosialdeparte- } \\
\text { mentet } \\
\text { Pb } 8019 \\
0030 \text { Oslo, Norge }\end{array}$ & +4722246939 & emj@aid.dep.no \\
\hline Ola Ribe & $\begin{array}{l}\text { Arbeids- og sosialdeparte- } \\
\text { mentet } \\
\mathrm{Pb} 8019 \\
0030 \text { Oslo, Norge }\end{array}$ & $\begin{array}{lll}+47 & 22 & 24 \\
47 & 10 & \end{array}$ & ola.ribe@aid.dep.no \\
\hline Anna Santesson & $\begin{array}{l}\text { Näringsdepartementet } \\
10333 \text { Stockholm } \\
\text { Sverige }\end{array}$ & +4684051234 & anna.santesson@industry.ministry.se \\
\hline John Pettersson & $\begin{array}{l}\text { Enheten för arbetsrätt och } \\
\text { arbetsmiljö på Näringsde- } \\
\text { partementet }\end{array}$ & & john.pettersson@industry.ministry.se \\
\hline
\end{tabular}

